\title{
La imagen de Felipe II en el Imperio Germano-Romano y en la historiografía alemana y austríaca
}

\author{
PeER SCHMidT *
}

\begin{abstract}
RESUMEN
Este artículo retraza la imagen de Felipe II en la historiografia de lengua alemana. Como España ejerció una posición hegemónica en Europa Central, y con relación al Reich ('Camino Español'), la imagen del Rey

Prudente no pudo ser sino negativa. Llama la atención que el rey atrajera el interés de historiadores tan importantes como Friedrich von Schiller y Leopold von Ranke. Los dos -como el público en general-se interesaron sobre todo

por la figura de don Carlos y el presunto papel de Felipe II en la muerte del principe. Ranke y su escuela se sintieron fascinados por la construcción y los problemas del Imperio español. Pero en general durante el siglo xx la historiografía en los paises de lengua alemana no mostró gran interés por el

Rey Prudente, ya que hasta la fecha carecemos de una biografía escrita por un historiador de lengua alemana.

\section{ABSTRACT}

This article outlines the image of Philip II in the German-speaking historiography. As Spain exercised a hegemonical position with regard to the 'Reich', and especially at its western territories ('Spanish Road'), the image of Philip was mainly a negative one. It is interesting to note that this king attracted the attention of some the most prominent historians in German language: Friedrich von Schiller and especially Leopold von Ranke; both as the German public- were interested (although not exclusively) in the death of Don Carlos and the possible role Philip played in it. Ranke and this followers were also fascinated by the size and problems of Spanish Empire. But generally speaking one could say that the "prudent king" stood not in the forefront of interest of German-speaking historians, as did Gustav Adolf, Richelieu or Louis XVI.
\end{abstract}

* Universidad de Erfurt. Alemania. 
El primer encuentro del futuro rey Felipe $/ 1$ con el mundo germano no se produjo bajo una buena estrella. El principe apenas había pisado territorios germanohablantes ${ }^{1}$ a comienzos del año 1549 , con motivo de su viaje de presentación, auspiciado e ideado por su padre, el Emperador Carlos V, cuando se vio confrontado con los agudos problemas políticos del Imperio. Acababa de terminar la guerra de Esmalcalda, en la cual Carlos $\mathrm{V}$ había infligido una derrota a la Liga protestante de Esmalcalda (24. 4. 1547). Vencidos los protestantes en la batalla de Mühlberg y fallecidos sus adversarios Enrique VIII de Inglaterra y Francisco I de Francia (1547) - Lutero había muerto en el año anterior-, Carlos $V$ parecía estar en el apogeo de su poder. Nadie en Europa le igualaba. Por lo tanto, Carlos V intentó aprovechar políticamente la victoria momentánea. Entre las medidas severas contra los luteranos figuraban la encarcelación de dos líderes de la Liga de Esmalcalda: el antiguo y destituido elector de Sajonia, Juan Federico, y el landgrave Felipe de Hesse. El landgrave había sido detenido en presencia de unos de los más destacados príncipes en el Imperio, de los electores de Brandenburgo y de Sajonia, cuando presentó su excusa ante el Emperador ${ }^{2}$. La encarcelación del landgrave de Hesse fue el problema en el cual se vio involucrado inmediatamente el príncipe de Asturias. Mauricio, el nuevo elector de Sajonia, uno de los más prestigiosos señores del Reich, acudió a verle en Trento, pidiéndole ayuda para la puesta en libertad del landgrave.

En estas circunstancias Carlos había convocado la "Dieta férrea" ("geharnischter Reichstag") de Augsburgo de 1547/48, donde el Emperador esperaba conseguir un acuerdo con los protestantes. Se estableció el "Interim", que hubiera debido llevar a la casi completa extinción del protestantismo. Para presionar más a los protestantes reacios, Carlos dejó sus tropas españolas, que habían ya intervenido en la guerra de Esmalcalda, en las cercanías de

Hay que advertir que Felipe Il había pisado jurídicamente el Imperio Romano ya en el momento de embarcar en Génova. Formalmente su viaje por Italia del norte era ya un viaje por el Imperio, puesto que Italia del Norte - salvo Venecia-pertenecia al Imperio. Sobre este aspecto, véase, vON ARETIN, “Die Lehensordnungen in Italien im 16. und 17. Jahrhundert und ihre Auswirkungen auf die europäischen Politik. Ein Beitrag zur Geschichte des europäischen Spätfeudalismus", en Weber, H. (ed.), Politische Ordnungen und soziale Kräfte im alten Reich. Wiesbaden 1980, págs. 53-84. En este sentido veáse también EoElMAyer, F., Maximilian //., Philipp II. und Reichsitalien. Die Auseinandersetzungen um das Reichslehen Finale in Ligurien. Stuttgart 1988.

Los dos electores habian acompañado al landgrave a la ciudad de Halle, donde Carlos $V$ habia residido después de la batalla. El landgrave pidió excusa y los tres protestantes esperaban el indulto. Pero Carlos $V$, quien sólo se habia comprometido a no encarcelarle durante un largo plazo, procedió a su arresto. RANKE, L. V., Deutsche Geschichte im Zeitalter der Reformation. Sämmtliche Werke. 5. ed. Berlin 1873, Tomo 4, págs. 381-388. 
Augsburgo ${ }^{3}$. Pero la dieta no consintió un fortalecimiento de los órganos centrales del Imperio y del papel del Emperador ${ }^{4}$. Carlos se concentró en lograr un acuerdo en favor de su propia casa: la formación del Círculo de Borgoña, que englobaba básicamente Flandes y el Franco-Condado, territorios que luego heredaría Felipe $1 \mathrm{I}^{5}$. Carlos, otra vez frustrado políticamente y agobiado físicamente, se resintió de la resistencia de la Dieta y comenzó a plantear de nuevo el tema de la sucesión imperial. En vez de los hijos de su hermano Fernando I, quien ya había sido coronado Rey de Romanos (1531) - y por lo tanto designado sucesor en el trono imperial-, Carlos favoreció ahora a su hijo Felipe (Spanische Sukzession). Bajo estas circunstancias se produjo el primer encuentro del futuro rey Felipe II con el mundo germánico.

Aunque en un principio la postura hacia Felipe en el mundo germánico fuera algo positiva $-y$ se esperara alguna mediación en el conflicto con el landgrave de Hesse-, Felipe iba a ser el heredero de la imagen esencialmente negativa que de los españoles ya se había formado durante la vida de su padre ${ }^{6}$. A lo largo de la primera mitad del siglo xvi muchos alemanes - y no sólo los protestantes- se habian vuelto cada vez más hostiles a la línea española de los Austrias. Por su política hegemónica Felipe II se vinculó intimamente con los destinos del Imperio. Pero no interesa aquí la política española como tal -aunque ésta ofrezca todavía muchos temas de investigación 7 sino más bien la percepción de esta política.

RaBe, H., Reichsbund und Interim. Die Verfassungs- und Religionspolitik Karls V. und der Reichstag von Augsburg 1547-48. Köln-Wien 1971, pág. 181. Id., Reich und Glaubensspaltung. Deutschland 1500-1600. Neue Deutsche Geschichte 4. München 1989, págs. 265ss.

Rabe, H., Reich ... (nota 3) pág. 267.

RABE, H., Reichsbund und interim ... (nota 3) págs. 361-398

En lo que se refiere a la opinión de los alemanes acerca de Carlos y su imagen estamos mucho mejor informados que en lo relativo a su hijo. Para el primer encuentro, véase, Peter, W.. "Probleme der deutsch-spanischen Begegnung in den Anfängen Karls V.". Spanische Forschungen, vol. 26 (1971), págs. 89-150. PINETTE, G. L., «Die Spanier und Spanien im Urteil des deutschen Volkes zur Zeit der Reformation". Archiv für Reformationsgeschichte, 48 (1957), págs. 182191. ARNOLDSSON, S., La leyenda negra. Estudios sobre sus origenes. Göteburgs Universitets Arsskrift 46, 3. Göteburg 1960, se dedica a la reacción alemana, sobre todo en los primeros años del siglo xvi. WALDECK, O.. "Die Publizistik des Schmalkaldischen Krieges in bezug auf die Frage nach dem Grund des Krieges und nach dem Recht des Widerstandes gegen den Kaiser". Archiv für Reformationsgeschichte, 7 (1909/10), págs. 1-55, y 8 (1910/11), págs. 44-133. HüriNs, E., "Nationale Propaganda im Schmalkaldischen Krieg», Zeitschrift für Geschichtswissenschaft, 6 (1958), págs. 1027-1248. POFTL, K., «La imagen de Carlos $V$ en las canciones populares históricas de los alemanes", Hispania, 30 (1970), págs. 397-410. KOHLER, A., "Bie spanisch-österreichische Begegnung in der ersten Hälfte des 16. Jahrhunderts. Ein mentalitätsgeschichtlicher Versuch», en KRÖMER, W. (ed.), Spanien und Österreich in der Renaissance. Akten des Fünften Spanisch-Österreichischen Symposions, 21.-25. September 1987 in Wien. Innsbruck 1989, págs. 43-66.

En este sentido véase, Edelmayer, F., Söldner und Pensionäre. Das Netzwerk Philipps II. von Spanien im Heiligen Römischen Reich. Habilitationsschrift, Wien 1998. 
El personaje de Felipe II resulta aún más atractivo para este propósito, ya que llegó a ser para los alemanes el prototipo del rey español, como lo prueban los juicios de los historiadores del siglo $x^{8}{ }^{8}$. Si bien Felipe II mereció varias biografías escritas por autores de lengua alemana, todavía no hay ningún estudio sistemático acerca de su imagen en la historiografía de los países germanohablantes. En este sentido este artículo sobre la percepción del Rey Prudente en el mundo germánico, desde su primer contacto personal hasta el debate en torno a su política y personalidad en la historiografía alemana de los siglos $\mathrm{xI} x \mathrm{y} \mathrm{xX}$, constituye un primer avance. Claro está que en algunos momentos tengo que reconocer lagunas, puesto que la prospección bibliográfica no siempre resulta fácil ${ }^{9}$. Todavía estamos lejos de tener un elenco con las publicaciones en favor y en contra de España y su monarca. Tampoco disponemos de un catálogo de las hojas volantes del siglo XVI. En general se puede constatar que Felipe II no generó tanto interés historiográfico entre los alemanes, austríacos o suizos como lo suscitaron otros monarcas extranjeros de la Contrarreforma y de la época de la confesionalización que intervinieron en los destinos del Reich, los cuales recibieron mucha más atención por parte de los historiadores germanohablantes, tales como Enrique IV, Richelieu y sobre todo Gustavo Adolfo, "salvador" del protestantismo alemán y gran propagandista de sus acciones en el suelo del Imperio.

El presente estudio se divide básicamente en cuatro capítulos que reflejan las diferentes fases de la formación de la imagen de Felipe II a lo largo de la historia y cultura centroeuropeas. Primero hay que considerar en las relaciones de los contemporáneos. Luego hay que dedicarse a la época de la Contrarreforma o confesionalización en su conjunto, donde el aspecto religioso juega desde luego un papel de primer rango. En el siglo xvill y con la llustración conocemos una tercera aproximación a la imagen del Rey Prudente desde el punto de vista de la Enciclopedia. La cuarta fase coincide mayoritariamente con la época del historicismo y su interés en las fuentes - acerca de don Carlos (sobre todo) - y la nueva evaluación de la figura del monarca.

Pero antes de seguir el desarrollo del primer encuentro de Felipe con el mundo germano, es preciso recordar algunos problemas y funciones de la

8 Marcks, E., "Philipp II", en Marcks, E./Müllef, K. A. v. (eds.), Meister der Politik. Eine weitgeschichtliche Reihe von Bildnissen. Stuttgart, Berlin 1922, págs. 561-591, aqui: 561. REINHOLD Baumstark, Philipp II. König von Spanien. Freiburg 1875, pág. 13

9 Aunque tengamos para el siglo XVI un valioso repertorio de los impresos publicados en los países de lengua alemana, esta bibliografía no tiene indice, con lo cual resulta sumamente dificil buscar títulos relativos a España o Felipe II, cf. Verzeichnis der im deutschen Sprachbereich erschienenen Drucke des XVI. Jahrhunderts ("VD 16»). 21 tomos. Stuttgant 1983-1994. 
percepción. Sabemos hoy que las imágenes son imprescindibles para el ser humano ayudándole a orientarse ${ }^{10}$. Siempre han existido y han jugado un papel importantísimo en la historia de las relaciones internacionales ${ }^{11}$ Lo complejo de este fenómeno socio-psicológico consiste en que la percepción se basa en hechos reales, pero además esta experiencia negativa o positiva se perpetúa. En vez de controlar constantemente la realidad y confrontarla con la imagen, la primera impresión se vuelve absoluta y perenne. Con esto la imagen corre el riesgo de convertirse en un estereotipo, que en vez de ayudar a un individuo o grupo, le puede desorientar. Al fin y al cabo, la imagen es tan real como los propios hechos. Res factae et res fictae forman un conjunto indisoluble. Pero el problema consiste en que la imagen sólo refleja parte de la realidad. Poco importa si una potencia prosigue cierta política, el solo hecho de presumirlo y sospecharlo basta para poner en alerta a otro grupo, como lo vivimos en la época de la Guerra Fría ${ }^{12}$.

La percepción del otro se forma en un proceso de comunicación ${ }^{13}$. Por lo tanto, la imagen en un principio se puede crear de nuevo cada vez y es susceptible de cambios. Los medios de comunicación son por lo tanto imprescindibles para la creación de imágenes. En este caso se trata primordialmente de discursos, memoriales y, sobre todo, la publicística de la época en forma de pasquines, hojas volantes y libelos, pero también canciones.

Pero la imagen no sólo se refiere al otro. Una de las funciones de la imagen del otro es la reflexión sobre el propio ser. Al definir al otro, un individuo o grupo se determina su propia esencia. Esta auto-imagen puede ser positiva en el sentido de identificación con otro grupo -o negativallevando al rechazo del otro o a la proyección de malas acciones atribuidas al otro. Indudablemente la propia particularidad se define en este proceso de comunicación. Los discursos, los diálogos y los grabados ayudan a la formación de la propia identidad. Se ha constatado que las imágenes referentes a rasgos nacionales gozan de mucha longevidad. Como Felipe

10 Boulding, K., The Image. Knowledge in Life and Society. 11. ed., Ann Arbor 1977.

1 NIEDHART, G., "Perzeption und Image als Gegenstand der Geschichte von internationalen Beziehungen. Eine Problemskizze", en WENDT, B. J. (ed.), Das britische Deutschlandbild im Wandel des 19. und 20. Jahrhunderts. Bochum 1984, págs. 39-52. Véase el tomo de Bosbach, F. (ed.). Feindbilder. Die Darstellung des Gegners in der politischen Publizistik des Mittelalters und der Neuzeit. Köln, Weimar, Wien 1992.

12 NIEDHART, G., "Western Attitudes Toward the Soviet Union: Perceptions and Misperceptions", en Intriligator, M. D./ Jacobsen, H.-D. (eds.), East-West Conflict. Perceptions and Political Options. Boulder, Col. 1988, págs. 5-18.

13 Bouloing, K. The Image ..., passim. 
continúa - a grandes rasgos - la política de su padre recurriendo a los mismos medios, se siguen proyectando las imágenes en torno a los españoles originadas a comienzos del siglo xVI. Con Felipe no se inaugura una percepción alemana totalmente nueva acerca de los españoles y su monarca. Muchos de los estereotipos que se proyectan sobre Felipe son herencia de su padre y demuestran así este fenómeno de larga duración.

Felipe llegó a Alemania en un momento clave de su historia. La visita del elector sajón en Trento era indudablemente expresión de las tensiones en el Imperio. Mauricio pedía al Infante que procediera en favor del landgrave encarcelado, que entretanto había sido llevado a Flandes, a Malinas ${ }^{14}$. La posición del elector era, a su vez, muy delicada. Debía su rango de elector al hecho de que había ayudado al Emperador en contra de sus correligionarios, siendo él mismo luterano. Por cierto, Carlos $V$ no había legitimado su guerra contra la Liga de Esmalcalda por motivos religiosos, sino por cuestiones jurídicas, inculpando a los miembros de la Liga de haber infringido el derecho del Imperio, un argumento que no fue aceptado por la mayoría de los protestantes ${ }^{15}$. No obstante, con su postura en favor de la casa de Habsburgo, Mauricio había traicionado su propio campo religioso. La razón política le llevó a cooperar con el Emperador, porque Carlos le prometió la posibilidad de ser uno de los siete electores del Imperio (Kurfürstenwürde) ${ }^{16}$. Para salvar por lo menos parte de su imagen pública, el nuevo elector y duque de Sajonia se vio comprometido a conseguir la liberación del landgrave; la opinión pública ya le había tachado de "Judas von Meißen". Además gozó de mala fama por ejecutar él mismo el bando imperial (Reichsacht) contra la ciudad protestante de Magdeburgo en nombre del Emperador, lo cual aumentó aún más las sospechas en contra del nuevo elector. En estas circunstancias, Mauricio había apostado por la interpelación ante Felipe para que éste hablase con su padre, y se decidió a ir a Trento a ver al futuro rey de España. Todavía a comienzos del mes de enero el sajón había rechazado un viaje que los

\footnotetext{
14 Brandi, K., Kaiser Karl V. Werden und Schicksal einer Persönlichkeit und eines Weltreiches. 2 tomos. München 1937-41, tomos, tomo 1, pág. 507.

is Rabe, H.. Reích... (nota 3), pág. 261.

16 Carlos legitimó este cambio por la traición del antiguo elector, quien se habia atrevido a hacer la guerra a su señor, el Emperador. Para proceder a esto, Carlos quitó la dignidad electoral a la línea ernestina de la Casa de Wettin - Casa de Sajonia- y lo transfirió a la línea ernestina, con sede en Meißen y Dresden.
} 
hijos del landgrave le habían pedido, aduciendo ser mala estación, como acabamos de saber gracias a la correspondencia recién editada de la chancillería sajona ${ }^{17}$. Pero quince días más tarde ya estaba en camino hacia el sur, hacia los Alpes. Estaba preparado - junto con el elector de Brandenburgo- a pagar un precio muy alto: consentir en la sucesión del Infante español al trono imperial ${ }^{18}$. El propio landgrave había propuesto a los dos electores apoyar una posible candidatura de Felipe a la dignidad imperial en caso de que muriera Carlos $V{ }^{19}$. Felipe, asesorado por el cardenal Cristofo Madruzzo, prometió dirigir una solicitud a su padre ${ }^{20}$. El gesto del elector era aún más importante cuando consideramos las condiciones: Mauricio emprendió el viaje pasando por los Alpes en pleno invierno, en una temporada de heladas y fríos terribles, aun para los alemanes.

Mientras los señores luteranos apostaban por la mediación del príncipe, los proyectos del Interim y de la sucesión en favor de Felipe causaron reticencias entre la opinión pública protestante. La aplicación del Interim había provocado el despido de alrededor de 400 pastores protestantes en el norte de Alemanía ${ }^{21}$. Está claro que los luteranos temían entonces "una servidumbre bestial, insoportable y eterna, como en Hispania» («viehischen, unerträglichen und ewigen Servitut, wie in Hispania") ${ }^{22}$. Sin duda alguna, este momento marcó un nuevo tono en la propaganda anticatólica. Significó un nuevo hito después de la oleada de pasquines y libelos de la Reforma de los años veinte, cuyo contenido anti-hispánico todavía no ha sido estudiado debidamente ${ }^{23}$.

Frente a las presiones políticas de Carlos $V$ sobre los estados y miembros de la Dieta surgieron inmediatamente acusaciones antiespañolas que irían haciendo daño a la imagen del príncipe de Asturias. Podemos aprender de la correspondencia del elector sajón que ya en el año de 1549 corrieron

Antwort des Kf. Moritz auf die Werbung von Statthalter und Räten zu Kassel durch Hermann von Hundelshausen und Christoph Hülsing, en Politische Korrespondenz des Herzogs und Kurtürsten Moritz von Sachsen. Band IV: 26. Mai 1548 - 8. Januar 1551. Ed. por J. HerrmanN und G. WARTENBERG. Berlin 1992, tomo IV [citado en adelante como PKMS], No 244, pág. 287.

18 Born, K. E., Moritz von Sachsen und die Fürstenverschwörung gegen Karl V. Darmstadt 1972, pág. 24.

19 “Artikel von Lanidgraf Philipp», PKMS, No 256, antes del 20 de enero de 1549, págs. 300301

20 Esto lo escribe el elector a Christina, la landgrave, Kf. Moritz an Landgräfin Christina, 24. Februar 1549, en PKMS, No 285, págs. 328s. Mündliche Antwort von Kf. Moritz an Kaspar Bodenhausen, 25. Februar 1549 , No 288 , págs. 333s.

21 RaBe, H., Reich (nota 3), pág. 278.

22 Vease Brandi, K., Kaiser Karl V.... (nota 14), tomo I, pág. 516.

23 RABE, H., Reich (nota 3), pág. 278. Para la severa crítica al Emperador con motivo de la batalla de Esmalcalda, véase también la bibliografía en la nota 6 . 
rumores entre los protestantes de que Felipe iba a ser el futuro Emperador y que seguiría inmediatamente a su padre, aun pasando por alto al propio rey de Romanos, Fernando, designado para la sucesión imperial ya en $1531^{24}$. Pero lo que era aún más grave: pronto se sospechó una acción militar de Carlos $V$, de su hermano Fernando y de Felipe contra los protestantes. Se temía a mediados de febrero de 1549 -Felipe estaba todavía en el sur de Alemania- que unos 1500 caballeros reclutados bajo el "pretexto" de acompañar al príncipe español, servirían en realidad para una acción bélica concertada de los Austrias buscando imponer el Interim ${ }^{25}$. En una carta el elector protestante de Brandenburgo saluda a Felipe mediante un mensajero, alegando que el príncipe mismo sabrá cuántos problemas religiosos había sufrido el Imperio en los últimos tiempos ${ }^{26}$. La advertencia no podía ser más clara.

No existe unanimidad en la historiografía germanohablante referente al proyecto de sucesión preconizado por Carlos V. Hay diferentes versiones en los manuales de historia alemana. Mientras que Ranke, Hartung, Rassow y Born subrayan la intención del Emperador de hacer seguir inmediatamente a Felipe en la dignidad imperial, Fuchs, Moeller, Lutz, Rabe y Schilling - basándose en el tratado del 9 de marzo de 1551- presentan la solución de que Felipe hubiera accedido sólo después de Fernando ${ }^{27}$.

24 Erasmus Schatz an kfl. Räte, Amberes, 14. Februar 1549, págs. 317s., en PKMS, No 274, págs. 317. En el mismo sentido: "denn Philipp kommt nicht ohne Grund" ("por algo será que Felipe viene"), dice el regesto del documento de "Artikel von Landgraf Philipp", en PKMS, No 256 , pág. 301 .

25 Begleitschreiben zu einer Zeitung, mediados de febrero de 1549, en PKMS, No 277, pág. 319.

26 Werbung des Kt. von Brandenburg an Prinz Philipp von Spanien durch Christoph von der Straßen, Hardt, 14. März 1549, en PKMS, No 298, págs. 344-345.

27 Ranke, L.V., Deutsche Geschichte... (nota 2), Tomo 5, pág. 84. Hartung, F., Karl V. und die deutschen Reichsstände von 1546-1555. Halle a. d. S. 1910. Reimprenta Darmstadt 1971, págs 53s. Rassow, P., Karl V. Der letzte Kaiser des Mittelalters. 2 ed. Göttingen 1963, pág. 55. BoRn, K. E., Moritz ... (nota 18), págs. 6-7. En contra de esta evolución, la posición de Fuchs, W. P., Das Zeitalter der Reformation. Gebhardt, Handbuch der deutschen Geschichte 8. Stuttgart 1970, pág. 193. Lutz, H., Das Ringen um deutsche Einheit und kirchliche Erneuerung. Von Maximilian bis zum Westfälischen Frieden 1490 bis 1648. Propyläen Geschichte Deutschlands 4. Berlin 1983, pág. 281. MOEl LeA, B., Deutschland im Zeitalter der Reformation. Deutsche Geschichte 4. 2. ed. Göttingen 1981, pág. 161. RABE, H., Deutsche Geschichte, págs. 429-430, quien no menciona este proyecto sino a partir de 1550. SchILLING, H., Aufbruch und Krise. Deutschland 1517-1648. Das Reich und die Deutschen. Berlin 1988, págs. 251-252. En su conclusión al tomo LUTZ, H., "Schlußwort: Zusammenhänge und Perspektiven", en, Ibidem, Das Römisch-Deutsche Reich im politischen System Karls V. Schriften des Historischen Kollegs. Kolloquien 1. München 1982, págs. 269-282, aquí págs. 278-279 evoca el problema de si tal vez el primer impulso de replantear el tema de la sucesión emanara de Fernando y su hijo Maximiliano, para eliminar definitivamente a los Habsburgos de Madrid de la dignidad imperial. También veáse la discusión en Rassow, P., "Forschungen zur Reichs-Idee im 16. und 17. Jahrhundert", en IDEM, Die geschichtliche Einheit 
Con la sospecha de que Felipe venía con intenciones bélicas, prosiguió su camino por la Alemania Alta hasta Flandes, un viaje que encontró un amplio eco desde el primer momento ${ }^{28}$. Mientras que Felipe era recibido en Italia y en Flandes con arcos triunfales, no le ofrecieron esta honra en los propios territorios del Imperio ${ }^{29}$. El libro de un tal Hans Heusel nos da la imagen de un príncipe joven, que se divierte con bailes ("alle nacht ain schöner fürstlicher Tanz/ unnd große pangket gehalten» ${ }^{30}$ ). Además hace hincapié en lo suntoso de los vestidos ${ }^{31}$. Nada de aquella ropa sencilla y de color negro que se conoce de Felipe siendo rey de España y Portugal. Sabemos por la descripción vivaz del viaje del sumiller de panadería, Vicente Álvarez, quien con un estilo muy directo caracterizó a su monarca sin caer en un estilo hagiográfico, que Felipe fue un príncipe al que le gustaba no sólo el baile, sino también mucho las mujeres ${ }^{32}$. Pero tampoco esconde los esfuerzos del príncipe por hacerse querer de los alemanes, cuando comía mucho o cuando bebía más de la cuenta. El sumiller de panadería no calla que Felipe tuvo cierto problema de adaptarse

des Abendlandes. Reden und Autsätze. Köln-Graz 1960, págs. 294-312, aqui esp. págs. 300-301 Si bien la sucesión directa de Felipe se basa tan sólo en rumores, Rassow hace hincapié en que Fernando creia en estos rumores

28 Lo demuestra la publicación de relaciones sobre su viaje por ltalia del norte. Se editaron por lo menos tres relaciones en cuatro ediciones: Kurter Bericht, welcher massen der Durchleuchtigst und hochgeborne Fürst, und Herr, Herr Philips der Röm. Key. May. Unnser aller Gnedigster Herrn Sun von Warcelona verruckt, inn Italian seinen weg genommen nochuolgennt zu Genua gerichten. Würzburg 1549 [Universitätsbibliothek München 4\% Hist. 4159,17]. Zyrlich Einreyten des Durchleuchtigsten Fürsten und Princeen auß Hyspania, inn die weytberühmbte Stadt Meylandt geschehen, den 19. tag Decembris Anno 1546. auß dem gedruckten Italischen Exemplar verteutscht. Dos ediciones: Würzburg: Johann Myller 1548 y Strasburg: Jacob Fröhlich. [Staatsund Universitätsbibliothek Dresden Hist. Hisp. 630,4] Además: Newe Zeittunge Des Durchleuchtigsten .... Herrn Philipsen. Printzen in Hispanien, Ertzherzogen zu Oesterreich, etc. einreitten, in die mechtigen Statt Meylandt, auff den 19. tag Decembris, des verschinen Jahs, AuB Italianischer Sprach in das Teutsche gebracht durch Caparn Scheidt. Worms 1549. Kurtzer Bericht, welcher massen der ... Fürst und Herr Philips ... zu Genua eingeriften ist deren ardt Ihme sehr grosse Ehr bewisen worden. 1549.

29 Una descripción muy detallada de estos arcos se halla en Cristoval CALVETE y ESTRELLA, El felicissimo viaie del muy alto y muy Podoroso Principe Don Philippe. Hijo de el Emperador Don Carlos Quinto Maximo desde España a sus tierras de la baxa Alemania... Amberes 1552. Como hay ejemplares de la obra de Calvete y Estrella en bibliotecas alemanas, es de suponer que en los círculos cultos se conocía también este libro. [Bayerische Staatsbibliothek München Res. 2 Hisp. 16; Staats-und Universitätsbibliothek Dresden Hist. Hisp. 51; Universitätsbibliothek Tübingen Fo I 30.2 ]. Hay otras relaciones del viaje de Felipe II en francés, latín o italiano en bibliotecas alemanas.

30 Heusel, Hans, Ain schen new Buch/lustig zu Lesen/den gantzen zug / und Raiß/ der Durchleüchtigsten Fürsten / und Herrn/ Herrn Philippo Printzen auB Hispanien. etc. Augsburg 1551, f. B. [Bayerische Staatsbibliothek München 4 Hisp. 12].

31 Id., Ain schen new Buch, i. C.

32. Sigo aquí la versión francesa editada por DOVILLEEE, M.T. (ed.), VICENTE ÁlvaREZ, Relation du Beau Voyage que fit aux Pays-Bas en 1548, le prince Philippe d'Espagne, Notre Seigneur. Bruxelles 1964, esp. págs. 56-57. 
"Le cardinal de Trente et lui dînèrent ce jour-là avec S.A. [Mauricio]; le repas fut très joyeux, on porta beaucoup de santés et je vis $S$. A. boire les fonds de verre des autres. C'était tellement étranger à sa condition que je compris qu'il faisait beaucoup de choses de ce genre-là pour faire plaisir aux gens, mais contre sa volonté. Cela doit être bien dur pour un aussi grand prince de dissimuler sa vraie nature et sa gravité et de sembler prendre plaisir à une chose si éloignée de sa condition” ${ }^{33}$.

Parece que los alemanes se dieron inmediatamente cuenta de este "esfuerzo cultural» por beber y comer mucho. Hasta hoy en día persiste la imagen de un príncipe algo torpe e incapaz de adaptarse a los alemanes. Pero el recuerdo de este primer contacto es algo contradictorio. Cuando Heusl o Vicente Álvarez nos presentan un príncipe al que le gustaba vestirse bien y bailar mucho, Karl Brandi (1890-1946), el biógrafo de Carlos V, nos ofrece la imagen de un príncipe sobrio. Según este historiador de Gotinga, los alemanes le calificaron como pacífico, concienzudo, pero también como un «joven poco vivo, quien recibió los homenajes de una manera embarazosa, formal y un poco molesto" ${ }^{34}$. Además Brandi hace hincapié en el contraste de los flamencos, amantes de la vida, y un príncipe supuestamente "seco" y algo aburrido. Brandi menciona también que Felipe se desmayó en un torneo y que el futuro rey español no aguantó el beber mucho y fuerte ${ }^{35}$. Heinrich Lutz, el historiador austríaco, transmite en el fondo la misma imagen de un príncipe incapaz de ganarse las simpatías de los alemanes. Menciona - sin indicar fuentes- una borrachera del español y su accidente en un torneo ${ }^{36}$. Según estas versiones eran atribuidas a Felipe las caracteristicas del "rey prudente». Pero según dichos autores el distanciamiento entre Felipe y los alemanes data ya del primer encuentro.

Al celebrar su Joyeuse Entrée en Bruselas en abril 1549, se dio entre los actos públicos una representación conmemorando la batalla de Mühlberg y la captura del antiguo elector de Sajonia, Juan Federico ${ }^{37}$. Claro está que con actos como este el príncipe no podía ganarse la confianza de los señores protestantes. Poco tiempo después Felipe volvió a Augsburgo,

\footnotetext{
33 Ibidem, págs. 65-66. Se trata de una comida junto con el elector de Sajonia y el cardenal de Trento. Esta preciosa relación es además una joya para conocer la imagen que de los alemanes tenian los españoles. El cortesano describe que los alemanes son sucios y groseros. De Augsburgo dice que el paisaje es bonito, pero la gente mala.

${ }_{34}$ BRANDI, K., Kaiser Karl V... (nota 14), tomo I, pág. 507.

Ibidem (nota 14), pág. 507

36 Lutz, H., Das Ringen... (nota 27), pág. 281. La noticia se encuentra en «Franz Kram an Kf. Moritz, en: PKMS, no 355, 28. April 1549, págs. 399-400.

Franz Kram an Georg Komerstadt, Brüssel, 2. April 1549, en PKMS, n 320, pág. 371.
} 
donde Carlos $\mathrm{V}$ siguió intentando conseguir la sucesión ${ }^{38}$, un proyecto que algunos señores luteranos estuvieron dispuestos a aceptar para conseguir la puesta en libertad del landgrave de Hesse ${ }^{39}$. Pero poco después ya se fueron enfriando las relaciones del príncipe con muchos señores alemanes. Cada vez era más obvio que Felipe no podía conseguir la liberación ${ }^{40}$. El príncipe mismo tuvo que confesar al elector sajón que su padre siempre reaccionaba muy enojado cuando le hablaba del caso 41. A mediados del año 1549 surgieron más comentarios agrios acerca de los españoles y su carácter ${ }^{42}$. Usando la expresión castellana "palabra" en el sentido de promesas vanas, el corresponsal de Mauricio en Bruselas dice con resignación refiriendose a las respuestas del príncipe sobre la liberación de Felipe de Hesse: "Aber es seind Palabres» ("Pero no son más que palabras") ${ }^{43}$. Además se iba reaccionando cada vez más contra las condiciones del encarcelamiento del landgrave custodiado por soldados españoles ${ }^{44}$. Y no callaron las voces que creían que Carlos quería acabar con el protestanismo y dejar luego el Imperio a su hijo ${ }^{45}$. Un incidente del 14 de agosto de 1550, cuando los españoles demolieron la Iglesia protestante de San Ulrico, sembró el escándalo en Augsburgo ${ }^{46}$. En los días de la Dieta hubo cada vez más comentarios negativos sobre los españoles ${ }^{47}$. De acuerdo con los rumores, se sentian ofendidos porque Felipe no había sido tratado con más honores que los electores ${ }^{48}$. El tratado de 9 de marzo de 1551 marca un hito en los esfuerzos por la sucesión imperial de Felipe, porque Fernando admite su

38 Se habla de esta intención en Erasmus Schatz an kfl. Räte, Antwerpen 14. Februar 1549 en PKMS, No 274, págs. 317s.

36. Artikel von Landgraf Philipp, vor dem 20. Januar 1549, en PKMS, No 256, págs. 300s

40 Franz Kram an Kf. Moritz, Brüssel, 23. März 1549, en PKMS, No 310, págs. 356s. Además Kf. Moritz an die jungen Landgraten zu Hesse, Tharandt, 3. November 1549, en PKMS, No 458, págs. 526ss. y Antwort von Kf. Moritz auf die durch Hermann von Hundelshausen, Konrad Diede und Heinrich Lersner überbrachte hessische Werbung, 18. Dezember 1549, en PKMS, No 470, págs. 542ss. nota.

"Prinz Philipp von Spanien an Kf. Moritz", en PKMS. No 433, 31. August 1549, pág. 502.

42. En una relación el corresponsal Franz Kram dice que los españoles ponen obstáculos a la liberación del landgrave donde pueden, Franz Kram an Kt. Moritz, 9. Mai 1549, en PKMS, No 368, págs. 408.

43 Franz Kram an Kt. Moritz, 24. Mai 1549, en PKMS, No 375, págs. 415s.

44 Franz Kram an Kf. Moritz, 9. Juni 1549, en PKMS, No 384, pág. 436. H(ieronymus) Jüngs an Johann Lersner, 14. Mai 1549 en PKMS, No 371, págs. $411 \mathrm{~s}$.

45 Franz Kram an Kf. Moritz, 12. August 1549, en PKMS, No 411, págs. 464-466.

4E Erasmus von Könneritz, Joachim von Kneutling und Franz Kram an Kf. Moritz, Augsburg, 17. August 1550, en PKMS, No 607, págs. 691-693.

1) Franz Kram an Georg Komerstadt, Augsburg, 16. August 1550, en PKMS, No 605, págs. 688-690.

48 Franz Kram an Kf. Moritz, 27. Dezember 1550, en PKMS, No 801, pág. 929 
intento de conseguir la elección del príncipe de Asturias a la dignidad imperial ${ }^{49}$.

Pero poco después se esfuman definitivamente los sueños imperiales de Carlos $V$ y del infante. Como el elector de Sajonia no había logrado nada en cuanto a la liberación del landgrave de Hesse, y como Mauricio, el albertino de la casa de Wettin, estaba amenazado con una posible reivindicación de la línea ernestina, el sajón albertino intentó asegurar su posición. Dresden comenzaba a negociar a partir de mediados del año 1550 con el rey francés ${ }^{50}$. A su vez, la casa de Habsburgo, dividida entre sí por la sucesión, posibilitó la actuación del duque de Sajonia ${ }^{51}$. A fin de ganarse el apoyo francés, Mauricio habló de la "servidumbre bestial" ("vihische servitut" ${ }^{52}$ de los españoles, que no sólo amenaza al Imperio, sino también a Francia. Mauricio formaba el centro de una alianza con el rey galo, que solicitó la liberación del príncipe alemán y la restauración de las "viejas libertades de nuestra tan querida patria de la nación alemana" ("alte libertet und freiheit unsers gelibten vaterlands der Teutschen nation») ${ }^{53}$. Carlos $V$ tardó mucho tiempo en averiguar la conjuración orquestada, porque creía que Mauricio le era fiel por deberle la dignidad electoral. Pero Mauricio se aprovechó de las diferencias entre Carlos y su hermano prometiendo a Fernando ayudarle en su lucha contra los turcos en Hungría. Dividia asi a la Casa de Austria en dos campos, puesto que éste era un punto en el cual Carlos apenas podía ayudar a su hermano ${ }^{54}$. Comienza así la "conjuración de los príncipes" ("Fürstenverschwörung"), durante la cual Carlos $V$ pierde todo el apoyo y el rey francés gana el vicariato sobre Toul, Verdun, Metz y Cambrai ${ }^{55}$. Cuando el Emperador se

4. Rabe, H., Reich ... (nota 3), págs. 281-283. Brand, K., Kaiser Kari V. ... (nota 14), págs. 512 s. Un resumen de la bibliografía en LAUBACH. E., «Karl V.. Ferdinand I. und die Nachfolge im Reich", Mitteilungen des Österreichischen Staatsarchivs, 29 (1976), págs. 1-51.

WartenduRg, G., "Die Politik des Kurfürsten Moritz von Sachsen gegenüber Frankreich zwischen 1548 und 1550", en DuCHHARDT, H./SCHMIT, E. (eds.). Deutschland und Frankreich in der Neuzeit. München 1987, págs. 71-102.

Aparte de Born, K. E., Moritz ... (nota 18), págs. 37ss. Véase también Cornelius, C. A., "Churfürst Moritz gegenüber der Fürstenverschwörung in den Jahren 1550/51", Abhandlungen der Historischen Classe der Königlich Bayerischen Akademie der Wissenschaften, X (1867), págs. 635-697

52 El tratado de Chambord del 15 de enero 1552 está publicado (en alemán) en DRUFFEL, A. V., Beiträge zur Reichsgeschichte 1546-1556. 4 tomos, München 1896, tomo III, No. 902, págs. 340-350, aqui: pág. 341 .

53 lbidem.

54 Born, K. E., Moritz ... (nota 18), págs. 40-41.

55 Fue el precio que pidió a los protestantes, una cláusula que el Emperador era incapaz de impedir. Se produce de esta forma el comienzo de la politica trancesa hacia el Rhin, Brand, K., "Karl V., Spanien und die französische Rheinpolitik», Historische Zeitschrift [abreviado en adelante HZ], 167 (1943), págs. 13-28. 
dio cuenta de la alianza, se encontraba en Innsbruck, sin tener tropas a su lado. Mauricio operó en el sur de Alemania cerrando el camino a los territorios del Rhin y de Flandes desde donde se hubiese podido socorrer al Emperador. Sus tropas en Italia estaban entonces combatiendo en Parma ayudando a los Farnesio contra el monarca francés y tampoco pudo reclutar otros soldados por falta de dinero:

"Nous ne trouvons personne, ne a Augsbourg, ny alleurs. que se veulle laisser persuader a nos accommoder de fiance..." 56

Pero la resistencia no sólo provino de los luteranos. Dentro de la propia Casa de Austria y del campo católico existieron muchísimas reticencias contra la política imperial. Especialmente el potente duque de Baviera -un católico acérrimo- estaba en contra de un posible fortalecimiento de la Casa de Austria.

Se terminó así el primer encuentro de Felipe con el mundo germano y la formación de una primera imagen del príncipe y futuro rey. La percepción de Felipe revela que hasta cierto punto la desconfianza hacia los españoles se repitió inevitablemente en la imagen del príncipe. El viaje del elector sajón en pleno invierno -además por los Alpes- demuestra que se creía en cierta posibilidad de influir y tratar con el principe español. De la postura del elector frente al príncipe de Asturias en los meses siguientes, se puede deducir que durante algún tiempo se consideró al príncipe capaz de lograr la liberación. Parece que hasta la corte del landgrave de Hesse esperaba resultados positivos del príncipe español ${ }^{57}$. Al no producirse los frutos esperados, la percepción de Felipe recayó en estereotipos. Frustrada esta experiencia, aquella parte de los protestantes que siempre había sido escéptica frente a la persona del monarca, obtuvo un triunfo.

Cuando el príncipe llegó a ser rey de España ya se había forjado en los territorios de habla alemana una imagen de los españoles. Tomando en cuenta las consideraciones generales sobre la larga duración de las percepciones, Felipe no inaugura un capítulo totalmente nuevo en la formación

\footnotetext{
56 Ostensible Instruction des Kaisers für J. de Rey an König Ferdinand, 3. März 1552, en Lanz, K., Correspondenz des Kaisers Karl, 3 tomos. Reimpresión. Frankfurt a. M. 1966, tomo III, No. 749 , págs. $98-108$.

57 Antwort des Kurfürsten Moriz auf die Werbung von Statthalter und Räten zu Kassel durch Hermann von Hundelshausen und Christoph Hülsing, PKMS, No 244, Torgau, 9. Januar 1549, págs. 287s. En el mismo sentido se expresa la landgrave al elector de Sajonia, Kassel, 21. März 1549, en PKMS, No 288 n. pág. 334.
} 
de la imagen del ser español. Lo que sí separa la época de Carlos $V$ de la de su hijo es el hecho de que Carlos tenía una relación más inmediata con los alemanes por ser Emperador. Aunque Felipe tuviera territorios de vasallaje imperial, como Milán y el Círculo de Borgoña, y aunque estuviese vinculado con el Reich, para los alemanes resultaba un monarca extranjero y extraño. Ya en el momento de planear la sucesión en el Imperio habia surgido un memorial que cuestionaba los derechos de Maximiliano y Felipe como sucesor de Carlos y su hermano Fernando. Uno de los argumentos claves en favor de la sucesión de Viena era el hecho de que Maximiliano conocía mejor a los señores alemanes. Felipe no hablaba el alemán y era señor de tierras muy lejanas como España, las Indias, Italia y África. Además se pretendió que por la presencia militar de los españoles en el Imperio había aún odio hacia su propia persona ${ }^{58}$. Como esta publicación no llevaba el nombre del autor, no se tiene la menor indicación sobre la intención. Puede tratarse de una maquinación protestante para dividir la casa de Austria. Pero tampoco hay que excluir que gozara de alguna aprobación por parte de los Habsburgos de Viena, que durante las deliberaciones familiares en torno a la sucesión imperial se quejaron de Felipe. Lo que veremos entonces durante la segunda mitad del siglo XVI es la formación y afirmación de la imagen de un rey español, un hecho todavía palpable en la historiografía hasta nuestro siglo.

Para situar la percepción en torno a Felipe en el mundo germano es imprescindible caracterizar la vida política en el Imperio y su vinculación con la Corona española. A pesar de la paz religiosa de 1555 Alemania vivía una época díficil y marcada por la diferenciación dentro del protestantismo. El reinado de Felipe II coincide en el Imperio con el surgimiento del calvinismo como tercera fuerza religiosa. La historiografía más reciente califica este proceso de la segunda mitad del siglo XVI como "segunda reforma" y -más recientemente-como "confesionalización", es decir como el proceso de regular la vida estatal, intelectual y social de acuerdo a la religión y cultura religiosa de los señores del Reich ${ }^{59}$. Después

58 Denkschrift über die Succession in der Kaiserwürde (en francés), Lanz, Kar! (ed.), Staatspapiere zur Geschichte Kaiser Karls V. Aus dem königlichen Archiv und der Bibliothéque de Bourgogne zu Brüssel. Bibliothek des litterarischen Vereins XI. Stuttgart 1845, págs. 450-464, aquí esp., pág. 459. También Brand, K., Kaiser Karl V. ... (nota 14), págs. 509-510.

59 SCHILlNG, H., "Die Konfessionalisierung von Kirche, Staat und Gesellschaft - Profil, Leistung, Defizite und Perspektiven eines geschichtswissenschaftlichen Paradigmas" en REINHARD, W./ SCHILling, H. (eds.), Die katholische Konfessionalisierung. Wissenschaftliches Symposion der Gesellschaft zur Herausgabe des Corpus Catholicorum und des Vereins für Reformationsgeschichte 1993. Münster 1995 (= Reformationsgeschichtliche Studien und Texte, Bd. 135), págs.1-49. SCHILLING, H. "Die Konfessionalisierung im Reich», Historische Zeitschrift 246 (1988), S. 1-45. 
de largas deliberaciones con teólogos y de largas horas de estudios en la $\mathrm{Bi}$ blia, el elector del Palatinado Federico III decidió convertirse al calvinismo en 1562. La Dieta de 1566, en la cual se trató de esta reforma, infringía la paz religiosa de Augsburgo de 1555, puesto que el acuerdo del "cuius regio, eius religio"se había limitado a los luteranos y los católicos. Pero el elector palatino impresionó a los miembros de la Dieta por su sincera piedad y religiosidad. Federico allanó el camino para el calvinismo en muchos territorios alemanes ${ }^{60}$. En total 86 miembros del Imperio (Reichsstände) siguieron este paso del Palatinado; entre 8000 y 9000 teólogos firmaron el Konkordienbuch, un libro resumiendo los principios religiosos más importantes ${ }^{61}$. Políticamente el establecimiento del calvinismo era de gran trascendencia, puesto que los adeptos del reformador de Ginebra eran mucho más radicales en su crítica de la Iglesia católica y del Papado. Heidelberg, la capital del Palatinado, llegó a ser un centro importante para refugiados e intelectuales calvinistas. Muchos territorios calvinistas estaban situados en el oeste del Imperio, cerca del "Camino Español' y de Francia, lo cual en ciertos momentos generó la perspectiva de acción comunes con el rey galo ${ }^{62}$. Claro está que esta constelación geopolítica no pudo dejar frío al monarca español. Las intervenciones de Felipe II en favor de señores alemanes católicos y la Contrarreforma encontraron desde luego en los calvinistas a sus más severos críticos, por razones políticas, religiosas y geoestratégicas.

Felipe intervino en varios momentos decisivos de la historia alemana de la segunda mitad del siglo XVI. Ya en 1556 impidió con su postura en favor del arzobispo y elector de Tréveris un intento de reforma calvinista ${ }^{63}$. Uno de los conflictos más importantes fue sin duda alguna la contienda en torno a la sede arzobispal de Colonia. El entonces arzobispo de Colonia, Gebhard Truchsess von Waldburg se casó con una monja protestante. Este acto condujo al intento, instigado por algunos miembros luteranos del cabildo eclesiástico, de una reforma protestante del arzobispado, la cual iba contra la paz religiosa de Augsburgo, que habia fijado que un clérigo-

so Ritter, M., Deutsche Geschichte im Zeitalter im Zeitalter der Gegenreformation und des Dreißigjährigen Krieges 1555-1648. 3 tomos. Reimpresión, Darmstadt 1962 [1889-1908]. Tomo I, págs. 279ss.

61 SchuLZE, W., Deutsche Geschichte im 16. Jahrhundert, 1500-1618. Frankfurt a. M. 1987, pág. 174-175.

62 Para las no siempre fáciles relaciones de los protestantes alemanes con el rey de Francia, véase p. ej. PLATZHOFF, W., Frankreich und die deutschen Protestanten in den Jahren 1570-1573. München, Berlin 1912.

63 NEY, J., Die Reformation in Trier 1559 und ihre Unterdrückung. 2 Hefte. Schriften des Vereins für Reformationsgeschichte 88/89. Halle 1906-07. 
señor católico sólo podía convertirse individualmente, pero estaba obligado a dejar los territorios y las instituciones intactas en manos de la Iglesia católica. El éxito de la reforma protestante en el señorío eclesiástico no sólo hubiera significado un drástico cambio de la mayoría protestante en el colegio de electores en favor de los protestantes (Sajonia, Brandenburgo, Palatinado - y Colonia), sino que hubiera tenido también graves consecuencias geopolíticas para la monarquía española. Se hubiera creado un conjunto de territorios reformados desde Inglaterra, pasando por los Países Bajos, Colonia y el Palatinado hasta Württemberg y Sajonia. España veía amenazado e interrumpido su "camino real». Estalló entonces la guerra de Colonia, en la cual un miembro del cabildo eclesiástico, Ernst von Bayern, el hijo menor del duque de Baviera, salió electo como nuevo arzobispo. Esta elección fue acompañada por acciones bélicas de tropas bávaras y españolas provenientes de Flandes.

Otro conflicto en el cual intervino Madrid fue la contienda confesional en Aquisgrán ${ }^{64}$. En la ciudad de Carlomagno la mayoría protestante iba a dominar a los católicos. Para impedir un gobierno municipal luterano, se intervino en 1598, restableciéndose el dominio católico minoritario. En Suiza, el acuerdo entre los cantones católicos y el Rey Prudente en 1587 suscitó temores por parte de los calvinistas ${ }^{65}$, lo cual provocó una reacción ${ }^{66}$. Todavia falta por estudiar el reflejo de esta angustia en forma de libelos. Una fuerte influencia en la formación de la imagen de Felipe II la tuvo la rebelión de los Países Bajos, ya que muchos emigrantes flamencos huyeron a la Baja Alemania al colindante Círculo de Westfalia ${ }^{67}$. Un ejemplo de los vínculos entre la Alemania Baja y Flandes es Guillermo de Orange nacido en el castillo de Dillenburg (Hesse), que se había casado en segundas nupcias con la hija de Mauricio de Sajonia y tenía territorios en otras partes del Imperio.

\footnotetext{
${ }_{54}$ Véase al respecto el estudio clásico de LOSSEN, M., Der Kölnische Krieg. 2 tomos. Gotha, München, Leipzig 1882-1897. Para Aquisgrán, Schmı12, W., Verfassung und Bekenntnis. Die Aachener Wirren im Spiegel der kaiserlichen Politik (1550-1616). Frankfurt a. M. 1983.

6.5 Bolzern, R., Spanien, Mailand und die katholische Eidgenossenschaft. Militärische, wirtschattliche und politische Beziehungen zur Zeit des Gesandten Alfonso Casati (1594-1621), Luzern, Stuttgart 1982, págs. 28ss.

66 Der Alten, Löblichen, Mannlichen Eydegenossen oder Helvetier, betendige vereinigung vnnd Bündnusz Der sieben Catholischen Orthen löblicher Eydgenossenschaft. München (falso) 1588 [Staats- und Stadtbibliothek Augsburg 4 Gs. Flugschr. 511]. Asi como: Bestendiger Gegenbericht Auff etliche in der Siben Papistischen Orten der Eydgenossenschaff newlich fürbrachten Antwort eingefürte Glaubens Articul. S. I.1588 [Bayerische Staatsbibliothek München $4 \mathrm{H}$. ref. 356]. Cf. Además, Gilly, C., Spanien und der Basler Buchdruck bis 1600. Ein Querschnitt durch die europäische Geistesgeschichte aus der Sicht einer europäischen Buchdruckerstadt. Basler Beiträge zur Geschichtswissenschaft. Band 151. Basel, Frankfurt a. M. 1985, págs. 242ss.

${ }_{67}$ SChilling. H., Niederländische Exulanten im Reich im 16. Jahrhundert. Ihre Stellung im Sozialgefüge und im religiösen Leben deutscher und englischer Städte. Gütersloh 1972.
} 
Teniendo en cuenta este trasfondo de la política real, se forjó la imagen del español y de su rey. No obstante, hace falta una observación: aunque pocas veces se mencione el nombre de Felipe II y se hable más generalmente del "español", está claro que la crítica se refiere en última instancia al Rey Prudente. También es cierto que la percepción de Felipe II y de su monarquía es más bien negativa que favorable. Si resumimos los puntos en contra de Felipe II en el discurso antiespañol, hay que mencionar sin duda estos cuatro: la intención de establecer una monarquía universal, las devastaciones de los soldados españoles, el afán religioso manifestado por la Inquisición en Europa y América y la capacidad de sobornar a las cortes de los señores del Imperio. Como medios de comunicación favoritos para difundir la "leyenda negra" en Alemania, los enemigos del rey españal se sirvieron de los libelos y de los pasquines, así como de las canciones, de las cuales muchas fueron reproducidas en las hojas volantes ${ }^{68}$.

Sin duda alguna la acusación de mayor trascendencia fue la de aspirar a una monarchia universalis ${ }^{69}$. Bajo este lema se entendió la ambición de gobernar - y subyugar - todo el mundo. Como decía un folleto que se publicó al estallar la Guerra de los Treinta Años reflejando la política española del siglo anterior:

"Quiere [el rey español] expander su monarquia universal tan rebuscada sobre todo el Imperio Romano, y además a todos los reinos, países y provincias, como un gran Nabucodonosor o Alejandro Magno, para subyugar y dominar todo el mundo" ${ }^{70}$.

Durante el reinado de Carlos $\mathrm{V}$ la idea de un gobierno mundial sintonizaba con la tradición de los cuatro imperios, en la cual el Sacro Imperio Romano sería la última monarquía, la mayor y más espléndida del mundo ${ }^{71}$. La pretensión de ser un monarca mundial y el lema del Plus ultra tenían toda la justificación plausible y casaban felizmente con el título de Sacro Imperio

s8 Brednich, R. W., Die Liedpublizistik im Flugblatt des 16. und 17. Jahrhunderts. 2 tomos. Baden-Baden 1974, tomo I, pág. 13

69 Para todo este complejo vease, BosBach, F., Monarchia universalis. Ein politischer Leitbegriff der Frühen Neuzeit. Göttingen 1988.

70 Spanisch Mucken Pulver: Wessen man sich gegen dem König in Spanien und seinen Catholischen Adhaerenten versehen solle; Ein außführlicher schöner Discurs. 1620, pág. 4. El texto en alemán dice: "Alsdann auch seine langgesuchte universal Monarchy/ über das ganze Römische Reich: Fürters auch über alle andere Königreich/ Länder/ und Provincien auffzurichten/ und wie ein grosser Nebcadnezar oder Alexander Magnus, die gantze Welt bezwingen und beherrschen.»

1 GOEZ, W., Translatio Imperii. Ein Beitrag zur Geschichte des Geschichtsdenkens und der politischen Theorien im Mittelalter und in der frühen Neuzeit. Tübingen 1958 
Romano ${ }^{72}$. Con Felipe 11 los alemanes tuvieron que reconocer que la potencia mundial era España, y que la reivindicación alemana de constituir un imperio habia llegado a ser - salvo en el aspecto escatológico y de la tradición jurídica- sumamente cuestionable ${ }^{73}$. De hecho los teólogos-juristas españoles se expresaron en contra de las pretensiones del Sacro Imperio Romano ${ }^{74}$. Una de las acusaciones de los alemanes era que Felipe quería constituir una quinta monarquía, que según la Biblia sería la del Anticristo. Pretender -como presumía el monarca español-gobernar todo el mundo era para los protestantes alemanes un sacrilegio, puesto que entre los luteranos la idea de las cuatro imperios como concepto escatológico gozaba todavía de amplia validez ${ }^{75}$. La acusación de crear una quinta monarquía -que infringiría la providencia divina- se convirtió en un tópico desde la época de Felipe $1{ }^{76}$. Pero el afán de gobernar todo el globo no constituye la única connotación de monarchia universalis. Se cuestionaba además la cualidad de dicho régimen. Según este concepto la monarquía española iba sobre todo en contra de la "Libertät», la libertad y los privilegios de los miembros del Imperio. Se temía la destrucción de este sistema político sumamente difícil y complejo. De ahí la constante acusación de la servidumbre española. Cabe resaltar además que los alemanes fueron muy conscientes de que España no era simplemente un poder europeo, sino que la monarquía tenia un fuerte pilar en el Nuevo Mundo ${ }^{77}$.

La "Apología" de Guillermo de Orange de 1581, que era muy conocida en Alemania, se hizo eco de estos temores y conceptos ${ }^{78}$. Primeramente

\footnotetext{
Hans-Joachim König demuestra que el ideario de Carlos $V$ estaba todavia determinado por conceptos medievales. KoniG. Hans-Joachim. Monarchia Mundi und Res Publica Christiana. Die Bedeutung des mittelalterlichen Imperium Romanum für die politische ldeenwelt Kaiser Karls $V$. und seiner Zeit, dargestellt an ausgewählten Beispielen. Diss. Hamburg 1969

No puedo aqui entrar en los complicados debates y conceptos de to que era una monarquía universal en los siglos XVI y XVII. Véase mi trabajo de próxima publicación. SCHMIDT. P.. Das spanische Imperium in der Propaganda des DreiBigjährigen Krieges. [El imperio español en la propaganda de la Guerra de los Treinta Años]

it Cf. Jlian de Salazar, Politica española. Madrid 1945, esp. págs. 19 y 24-25.

's Sobre el cambio del concepto de la cuarta monarquía véase tambien, SEIFFtr, A., Der Rückzug der biblischen Prophetie von der neueren Geschichte. Studien zur Geschichte der Reichstheologie des frühnzeuzeitlichen deutschen Protestantismus. Köln, Wien 1990.

it. Schmilot, P., Das spanische Imperium ...(nota 73), Cap. C. I.

77. Contrariamente a BosBach, F., Monarchia universalis ... (nota 69), pág. 75, sostiene que la monarchia universalis se referia especialmente a Europa; yo mismo he podido comprobar que este concepto era geográticamente mucho más amplio: el público alemán era muy consciente de que era una potencia politica con intereses en los cuatro continentes - expresándose asi una nueva visión del mundo, SCHMiDT, P., Das spanische Imperium ... (nota 73), Cap. C. I.

is Apologie otte Veranwoordinghe des Voerst en Herren Withelms vand Godes ghenade Prince van Oranghien Teghen den Ban ofte Edict by forme an Proscriptie ghepubliceert by den Coningh van Spaegnien teghen aen Myne Heeren de Generaele Staeten van de Niederlanden. Leyden 1581
} 
publicada en latín y con motivo de los sucesos en los Paises Bajos, pronto se traduce la amonestación de Philippe de Marnix de Sainte Aldegonde, que expresó los temores de una dominación y opresión españolas compartidos por alemanes y flamencos ${ }^{79}$. Junto con la Apología esta publicación constituye una de las más severas críticas directas a Felipe II en lengua alemana, ya que - contrariamente a muchas publicaciones anónimaseste libelo menciona personalmente al Rey Prudente. Del monarca espanol se dice que tenía "un afán insaciable de gobernar y un sentido de venganza cruel y sin razón que sólo podía impedir el juicio y la ley" ${ }^{80}$. Según el autor, el hijo de Carlos V simbolizaba al 'español típico' ("recht Spanische art») ${ }^{81}$, atribuyéndole la caracterización explicita de "ambición cruel» y "violencia» ${ }^{82}$. Se advierte a los alemanes que estén atentos a las intrigas de los españoles. Madrid y Felipe fueron aún más peligrosos, porque España estaba representada en la Dieta alemana. En este contexto se mencionan algunas "maniobras" de Felipe, como la muerte de Don Carlos. Con algunas actualizaciones este texto se imprimió seis veces hasta $1600^{83}$. En su agresividad esta publicación sobrepasa a muchas publicaciones alemanas. Esta tendencia radical del texto es muy representativa del tono severo de los holandeses, un tono que desde luego tenía que ser muy fuerte, si se queria justificar la sublevación contra el señor a quien habían prestado juramento de fidelidad. No cabia entonces otra alternativa que la de descalificar personalmente a Felipe.

Otro tratado de clara tendencia antihispánica era el de Las Casas sobre el monarca y sus limitaciones: De regia potestate (1571) ${ }^{84}$. Toda la publicación del tratado era una maquinación, puesto que -en contra de lo que

\footnotetext{
[Bayerische Staatsbibliothek München 4 Belg. 8,1]. Es de advertir que los alemanes en los territorios colindantes con Flandes entendian sin grandes problemas el holandés de aquel entonces.

Marnix de SAINTE ALDEGONDE: Ein sehr Nothwendige/Trewhertzige vnd Wolgemeinte warnung vnnd Vermanungs Schrifft: Darinne der Spanier Tyranney/List/ Anschlege/ vnnd Practicken wider die Christen entdecket/ vnd bey zeite jhre Gewalt zu brechen sey.... Ann alle Chur vnd Füersten/Stende vnd Staedte des heiligen Reichs Deutscher Nation/Vmb Den gemeinen Nutz Freyheit vnd Woltahrt der ganzten Christenheit zuerhalten. 1585. [Edición Gustav Freytag. Microficha No 2128]. Aquí la edición de 1599.

so Ibidem, "die vnersetliche begierd zu herschen/vnd die grausame vnsinnige Rachgirigkeit durch einigerley Gericht vnd Recht verhüt vnd begschrecket werden mögen", pág. 33.

Ibidem, pág. 15

lbidem, págs. 34-35

83 Cf. VD 16, tomo 2. Véase, HOFFMEISTER, G., "Das spanische Post- und Wächterhörnlein. Zur Verbreitung der Leyenda Negra in Deutschland (1583-1619)", Archiv für Kulturgeschichte, 56 (1974), págs. 350-371. Y BRIESEMEISTER, D., "'allerhand iniurien schmehkarten pasquill vnd andere schandlose ehrenrürige Schriften vnd Model'. Die antispanischen Flugschriften in Deutschland zwischen 1580 und 1635”, Wolfenbüttler Beiträge, 4 (1981), págs. 147-189, aqui, pág. 152.

8.4 D. Bartolomael DE LAS CASAS, De regia potestate. Frankfurt a. M. 1571.
} 
dice el prólogo de la publicación- un tal "Wolfgang Griesstetter», que pretendía que Las Casas le había entregado el manuscrito ${ }^{85}$, probablemente nunca existió. Si bien es cierto que el tratado es de la autoría de Las Casas, las circunstancias de su publicación son típicas de las maniobras en relación con la imprenta. Un tal «Wolfgang Griesstetter» nunca trabajó en Espira, ni parece haber participado en el séquito del encargado imperial Adam de Dietrichstein ${ }^{86}$. Era corriente servirse de una persona ficticia o ya muerta para la publicación de libelos o impresos de este tipo. El tratado intenta demostrar los límites del poder real, que tenía que respetar las leyes y las costumbres del pueblo que gobernaba. Claro está que la publicación latina encontró ávidos lectores entre el público culto alemán ${ }^{87}$.

Desde la época de Carlos $V$ la primera imagen que prevaleció fue sin duda la del español como soldado. Carlos vino de la batalla de Pavía con tropas -en parte españolas o bajo el pabellón castellano- que acabaron con la guerra de los campesinos en la Alta Alemania ${ }^{88}$. Luego la batalla de Mühlberg contribuyó a mantener esta imagen: Carlos tuvo consigo alrededor de 8000 soldados "españoles" ${ }^{89}$. Al estacionar las tropas durante la Dieta de Augsburgo cerca de la ciudad, confirmó los temores de los protestantes. Felipe iba a profundizar esta percepción del guerrero español por las intervenciones arriba mencionadas. Daba igual en estos momentos que los soldados no fueran en parte no castellanos, sino flamencos o italianos - como en la guerra de Esmalcalda ${ }^{90}$; lo importante era que el mando militar estaba en manos de un español o que las tropas lucharon bajo la bandera española ${ }^{91}$. Que los españoles cometían todos los horrores de la guerra posibles, no hace falta describirlo aquí con la misma prolijidad que los pasquines ${ }^{92}$. Hay que repetir en este contexto que todavía

85 Esta versión la dan Gonzalez Rodriguez, J., "Introducción. Dimensión histórica del "De Regia Potestate" ", en Fray Bartolome de las Casas, De Regia Potestate. Quaestio Theologalis. Obras Completas 12. Ed. por GonzÁlez Rodriguez, J. Madrid 1990, págs. XLI-LIX.

86 Schmidt, P., Das spanische Imperium (nota 73), Cap. C, I. VI.

${ }_{B 7}$ Se publica de nuevo durante la Guerra de los Treinta Años bajo el título de: Erudita et eligans explicatio Quaestionis: Utrum Reges vel Prinicipes, jure aligo vel titulo, et salva conscientia, cives ac subditos a Regis Corona alienare, et alterius domini particularis ditioni subjiecere possint? Tubinga 1625. [Bayerische Staatsbibliothek München 4 ph. pr. 92]

88 ARnOLdSSON, S., La leyenda negra ... (nota 6), págs. 30-33.

89 Ranke, L. V., Deutsche Geschichte ...(nota 2), pág. 311.

9 Brandi, K., Kaiser Karl V.... (nota 14), pág. 474

91 Ibidem, pág. 476.

92 Sobre la guerra en el Círculo de Westfalia, véase, Kurtze und warhaffte Anzeig und bereicht, Was sich jnnerhalb drey Monaten nechsthin in dem Niederländischen Westphelischen Creiß verloffen, unnd Viehisch deß Königs zu Hispania Kriegsvolck uff deß Reichs Grund unnd Boden ohne unterscheid wider männiglich bißhero hauBgehalten. 1599 [Universitätsbibliothek München 4 Hist. 4029]. 
no tenemos ningún repertorio que contenga los libelos antihispánicos de la época.

Claro está que la imagen del español guerrero se reflejó también en las hojas volantes, de las cuales todavía no tenemos ningún elenco, ni en general, ni para los de contenido luso-hispánico. Uno de los más conocidos pasquines antiespañoles data del año de 1569. Vemos al duque de Alba asesorado por el diablo y por el cardenal de Granvela. Las ciudades y regiones de Flandes, representadas por mujeres con los respectivos escudos, están arrodilladas y atadas por el cuello. En el fondo se ven las ejecuciones y a personas ahorcadas en árboles. Aquellas escenas parecen los grabados que conocemos de Theodore de Bry en sus ediciones de los tratados americanistas de Las Casas ${ }^{93}$. Otro medio de difusión popular fueron las canciones, de las cuales una protestante advierte:

«...Spannier sind kluge Leute, Los españoles son muy listos

Frankreich, und Engeland sind gerüst Francia, Inglaterra, todos están preparados, Warten all auff die Beute"

Todos esperan el botín" ${ }^{94}$.

Y en otra canción amonesta aún en contra de una alianza de los españoles con los turcos:

“Wann nür nicht hinderm Türcken

Etwa ein loser Hund,

Der Ihm ein loch zu wirken,

Mit inm gemacht ein bund,

Deutschland zu führen in angst

und Noth,

Durch Spannische list, und Bäpst tück, por la astucia española y el engaño papal,

Dein feinden wehr, ô Herr»,
Que no esté detrás del turco un perro suelto

al que prepara un camino y con él hace una alianza.

llevando a Alemania miedo y miseria

Al hablar de la "Armada" de 1588 se hace hincapié en la multitud de buques bajo el mando del rey español, una fuerza bélica que sirve para conquistar todo el mundo. El poeta se burla del fracaso de la expedición:

"Der Spanier hat mit Unzahl Schiffen El español tiene un gran número de buques Ganz überdeckt des Meeres Tiefen... que cubren el fondo del mar...

93 "Hie kann man warhaftig sehen... (1569)", reproducido en HARMS, W. (ed.), llistrierte Flugblätter aus den Jahrhunderten der Reformation und Glaubenskämpfe. Coburg 1983. No 69 págs. 144-145.

94 "Zwei Calvinistenlieder. Ein Alt New Liedt», en Soltau, F. L. v. (ed.), Deutsche historische Volkslieder. II tomos. Leipzig 1856, tomo II, págs. 283-285.

95 "An den Meißnischen Adel, en Friedrich Leonhard von Soltau, Deutsche historische Volkslieder, Il tomo, No 40, págs. 285-290, aqui pág. 290. 
Die Ursach ist Ehrsucht und Geiz..

Des Königs monarchischer Weltgeiz und die Geldgier seiner Untertanen"
La causa de todo esto es vanidad y avidez...

La ambición de ser monarca mundial y la avidez por el dinero de sus súbditos" ${ }^{96}$.

Que esta propaganda no sólo iba dirigida a la gente común, sino que expresaba también los temores de las cortes de muchos señores alemanes, se puede ver a través de los memoriales de los consejeros o en las resoluciones. La imagen del español guerrero figuraba también en la correspondencia y las deliberaciones de los Consejos. Así la confederación de territorios protestantes del Palatinado, de Baden y de Württemberg protestaron contra las crueldades de la soldadesca española ${ }^{97}$.

Como he advertido al principio, la imagen del otro refleja siempre la propia imagen. Por lo tanto, se aconseja siempre a los alemanes estar atentos, quedarse unidos y no dejar que Alemania se vea arrastrada por tropas extranjeras. Alarmar a la propia gente era también el próposito de una hoja volante del año de 1576, en la cual se veía un león (= Bélgica) que dormía ${ }^{98}$. Alrededor del león están los zorros (los comandantes españoles) que cazaban gansos. El mensaje era clarísimo: despiértate Bélgica para impedir las acciones españolas. En el Círculo de Westfalia, colindante con el de Borgońa, también se expresó la oposición entre los alemanes y los españoles en metáforas sacadas de la fauna - un medio de rétorica favorito de los libelos y hojas volantes-. Se habla de los Voesen y de los Goesen, es decir en el alemán contemporáneo de Füchse (zorros = españoles) y de los Gänse (gansos = alemanes) ${ }^{99}$. Goesen permitía además la asociación con los gueux, los "mendigos", como se llamaron los holandeses a sí mismos. Sin mencionar a Felipe II, no cabe duda de que en última instancia las críticas se dirigían contra el monarca español mismo. La mala imagen de Felipe II era sin duda alguna consecuencia de su presencia militar.

Al subir al trono Felipe II también se habia ya difundido otro gran tópico: la Inquisición española. Parece que la percepción de la Inquisición españo-

\footnotetext{
96 Johann Fischart, en Serapeum 1846 citado segun, PINETTE, G.L., "Die Spanier" (nota 6), pág. 188.

KLuckHOHN, A. (ed.), Briefe Friedrichs des Frommen, Kurfürst von der Pfalz, 1559-1576. 2 tomos. Munchen 1868-1873, tomo II, No 409, «Heidelberger Abschied «, abril 1567, pág. 245.

98 El grabado está reproducido/publicado, en HaRms, W. (ed.), Illustrierte Flugblätter des Barock. 4 tomos [hasta la fecha], tomo II. München 1982ss, pág. 68.

9. Véase también el catálogo de una exposición de la biblioteca universitaria de Münster VOESEN + GOESEN. Westfalen im spanisch-niederländischen Krieg (1566-1609). Ausstellungskataloge staatlicher Archive, 14. Münster 1982.
} 
la entró por medio de los judíos ${ }^{100}$ y los protestantes españoles refugiados en Alemania. Pero sobre esta migración de refugiados no sabemos prácticamente nada. Entre los exiliados se encontraba un tal Juan Díaz, un estudiante español que había frecuentado la universidad de Wittenberg, que compiló una biblia protestante en Neoburgo y halló la muerte a manos de su propio hermano Alfonso, un clérigo católico ${ }^{101}$. No asombra entonces que ya en 1548 se publicase un panfleto en alemán sobre las actividades de la Inquisición en Flandes ${ }^{102}$. La edición alemana del libelo de Marnix de SainteAldegonde y la Apología de Guillermo de Orange, así como el Antihispanus ${ }^{103}$, denunciaron las actividades de la Inquisición.

La estrecha vinculación «internacional» en la formación de la imagen antifelipista la demuestra el hecho de que ya en 1567 un tal Reginaldus Gonsalvius Montanus publicase su Historia inquisitionis sanctae en Heidelberg ${ }^{104}$. Detrás de este seudónimo se escondía seguramente un protestante de origen sevillano que había estado en Inglaterra: Casiodoro de Reina ${ }^{105}$. El conflicto con los Países Bajos tuvo inmediatas repercusiones en el Imperio, puesto que los flamencos se sirvieron de las instituciones imperiales, concretamente de la Dieta. Buscando el amparo del Reich, al cual pertenecían, los holandeses estuvieron presentes en la Dieta de Espira de 1570 , donde protestaron en contra de la política religiosa de los españoles ${ }^{106}$.

${ }_{100}$ Sobre su papel económico veáse KeLLENBEnz, H., Sephardim an der unteren Elbe. Thre wirtschaftliche und politische Bedeutung vom Ende des 16. Jahrhunderts bis zum Beginn des 18. Jahrhunderts. Wiesbaden 1958

101 La muerte de Juan Díaz causó malestar, porque Carlos no quería satisfacer y tratar debidamente las reclamaciones protestantes en la Dieta de Ratisbona de 1546, cf. Brand, K., Kaiser Karl V. ...(nota 14), pág. 467. Dio motivo para un poema, cf. LILIENCRON, R. V., Die historischen Volkslieder der Deutschen. 4 tomos. Reimpresión Aalen 1966, tomo III, pág. 384

102 Von der Unchristlichen, tyrannischen Inquisition, den Glauben belangend, geschrieben aus Niederland. s.t. 1548.

103 Antihispanus: Das ist Widerlegung Spanischer Unart, angemaBter Kron Franckreich unzeitiger Beherrschung. Leyden 1590 [Universitätsbibliothek München 4 Hist. 2141, 18]. L'Antiespagnol oder Ausführliche Erklerunge wie der König auss Spanien sich vnter dem Schein der Religion ohn allen rechmässigen Tittel ein Protector vber das gewaltige Frantzösische Königreich nennet. Basel 1590. [Herzog August Bibliothek, Wolfenbüttel Gk 2145 (7)]

104 Reginaldus Gonsalvius Montanus, Historia inquisitionis sanctae. Heidelberg 1567. [Universitätsbibliothek München $8 \mathrm{H}$ eccl. 409].

105 Por to vísto no se trató de Alonso del Corro, otro protestanie sevillano que había pasado a Flandes, como cree Vermaseren, 8. A., "Who was Reginaldus Gonsalvius Montanus?", Bibliothèque d'Humanisme ef Renaissance, XLVII (1985), págs. 47-77. En contra, Gilly, C., Spanien und der Basler Buchdruck, (nota 66), págs. 376-377.

105 Deutsche Reichstagsakten. Reichsversammlungen 1566-1662. Der Reichstag zu Speyer 1570. Ed. pot LANZINNER, M. Göttingen 1988, 2 tomos, tomo II, n² 491, pág. 1071. Igualmente una protesta de los vecinos de Nimega, $n^{\circ} 493$, pag. 1072. Deutsche Reichstagsakten, tomo II, $n^{\circ} 438$, pág. 1030. Los ciudadanos de Groninga protestaron contra el procedimiento del duque de Alba. 
En este contexto hay que situar la obra de Bartolomé de las Casas. Las ediciones del obispo chiapaneco fueran mucho menos frecuentes en el Imperio que en Flandes. En 1597 se editó su Brevísima Relación de la destrucción de las Indias en alemán, conocida por cierto desde los años cincuenta en círculos antiespañoles ${ }^{107}$. No obstante, ya Girolamo Benzoni había propagado en Alemania los hechos y crueldades de la conquista ${ }^{108}$. La actividad de la Inquisición no se limitó a Europa. Los protestantes europeos tuvieron una conciencia muy marcada de que España no sólo era un poder del viejo continente, sino también en el nuevo mundo. Que Felipe mantenía una estrecha relación con la Inquisición era el credo de todas estas publicaciones.

Prácticamente no conocemos hasta la fecha representaciones gráficas o retratos de Felipe. En este sentido cobra bastante importancia el grabado de alrededor de 1570 en el cual se ve al rex hispanicus. Está acompañado por un obispo y un miembro de la Inquisición. En la otra parte del grabado aparece un retrato del duque de Alba ${ }^{109}$. En lo que se refiere a la representación de Felipe II, se ve al rey vestido con la golilla. Este elemento del vestido será también el atributo gráfico para el español en los pasquines de la Guerra de los Treinta Años.

Pero la oposición protestante no era la única en la que se forjaba la imagen controvertida. En las cortes de Viena y Praga también había reservas contra el "primo" madrileño ${ }^{110}$. Se puede remitir a la opinión de Lazarus de Schwendi, un consejero y militar al servicio del Emperador que redactó un dictamen sobre el estado del Imperio, en el cual detecta los grandes males que afligen el Reich. Entre otros factores que estorban la paz y la tranquilidad menciona el sistema de pensiones. Los constantes sobornos corrompían a los señores. Esta crítica se dirigía directamente contra la política española y sus pagos a los príncipes alemanes ${ }^{111}$. La expresión los

107 Bartolomé de LAS CASAS: Neve Welt. Warhafftige Anzeigung der Hispanier grewlichen/ abschewlichen vnd vnmenschlichen Tyranney/ von jhnen inn den Indianischen Ländern... begangen. 1597. [Staats- und Stadtbibliothek Augsburg, 4 Gs. 1394].

108 La primera edición en alemán data del año 1579, Girolamo BENzoNi, Der Newen Weldt und Indianischen Königreichs, newe und waraffte History, von allen Geschichten, Handlungen. Thaten, Strengem und Ernstlichem Regiment der Spanier gegen der Indianern. Basel 1579. [Bayerische Staatsbibliothek München 2 Am. a. 38].

109 «Her nimpt mit gewalt dem rychtom», reproducido en, HARMS, W. (ed.). Illustrierte Flugblätter ... (nota 93), No 68, págs. 142s.

110 Sobre las relaciones entre las cortes de Maximiliano y Felipe, véase, EDELMAYER, F./KOHLER, A. (eds.), Maximilian II. Kultur und Politik im 16. Jahrhundert. München 1992.

111 LAZARUS VON SCHWENOI, "Discurs und bedencken über jetzigen stand und wesen des hailigen Reiches, unsers liben vaterlands" [c. 1570], publicado en LANZINNER, M., "Die Denkschrift des Lazarus von Schwendi zur Reichspolitik (1570)", Zeitschrift für historische Forschung. Beiheft 3 : Neue Studien zur frühneuzeitlichen Reichsgeschichte. Berlin 1987, págs. 154-185. 
"doblones españoles" que destruyen la moral de los alemanes estaba en boca de todos. Como se puede ver al consultar los avisos, los alemanes estuvieron atentos a las llegadas de la flota americana. Los buques americanos con su "oro" eran para la opinión pública un requisito importante de la hegemonía española. Aquí vemos también la función de la imagen, es decir en este caso concreto la afirmación de que las influencias nocivas venían de fuera de España. La tendencia exculpatoria de la propaganda por medio de panfletos y pasquines está claramente demostrada, cuando hace recaer la responsabilidad de todos los males en las influencias exteriores.

Cabe citar además al emperador Maximiliano II, casado con la hija de Carlos V, María. En 1548 Maximiliano había estado en España para traer a su futura mujer a Viena. Pero no guardó un recuerdo grato del país ibérico ${ }^{112}$. Cuando, a la vuelta de España, se trató de la sucesión en el Imperio, Maximiliano intentó evitar los contactos con Felipe $1{ }^{113}$. Una carta de Maximiliano Il a su tío en Madrid deja entrever una posición escéptica. La imagen de Felipe como rey severo se detecta en varias cartas, en las cuales el Emperador le pide extrema prudencia en los asuntos de Flandes ${ }^{114}$. En una carta Maximiliano advierte de la mala imagen que tiene España en el Imperio y que se refleja en canciones y poemas, en los cuales se pretende que los católicos estén unidos con el Papa para luchar contra los señores y otros miembros del Imperio. El Emperador mismo intentó proceder en contra de los autores de los malos poemas, venenosos y nocivos, que no sólo se publican en Alemania, sino de los cuales llegan también noticias desde Roma ${ }^{115}$.

112 Brandi, K., Kaiser Karl V. ... (nota 14), pág. 506.

113 Ibidem, pág. 512.

1 i4 Carta de Maximiliano a Felipe, 21 de septiembre de 1566, en BIBL, V. (ed.), Die Korrespondenz Maximilians II. Veröffentlichungen der Kommission für Neuere Geschichte Österreichs. Tomos 14 y 16 Reimpresión Vaduz 1970, Tomo 16, No 21, pág. 25. Carta de Maximiliano a Felipe. 7. März 1567, 181DEM, No 120, págs. 120-131. Maximiliano a Felipe II: 309 de septiembre de 1567, en IBIDEM, Tomo 16, No 223, págs. 228-232. También en este sentido, 21 de septiembre de 1566, Carta del Emperador Maximiliano a Margarita de Parma, 24 de marzo de 1566, en IBIDEM, tomo 14, no 394, págs. 476-478 Además Maximiliano escribió a Felipe II apelando a la clemencia del rey en favor del conde de Hoorn, Carta de Maximiliano a Felipe II, 20 de octubre de 1567, en lBIOEM, $n^{\circ} 230$, págs. 243-244.

115 Dice el texto en alemán: "Zumal dieweil auch ohe das nun ain guete zeit herumb durch boshaftige menschen nit allain inn-, sonder auch ausserhalb des reichs falsche gedicht ausgesprengt und in die leuthe hohes und nideres stands gestekt und gebildet worden, inmassen wir E.L. und ander mehr christliche catholische potentaten uns mit der Bäbstl. Htat verbunden hetten, ainen haubtkrieg wieder die verwandten der Augsburgischen confession anzufangen und die gantze Teutsche nation mit feur und pluet zu erfulien, wie dan solch figment in truk kommen und offentlich fail gehalten, auch in alle sprachen transferient und nit aliein im Teutschland heufig umbgetragen, sondern auch in allen andern kunigreichen empör geschwebt, als das uns dasselbe auch von Rom in welscher zungen verfast zugeschickt worden." en Maximiliano a Felipe II, 30 de septiembre de 1567, en BiBL, V. (ed.), Die Korrespondenz Maximilians $/ 1$... (nota 114), tomo 16. No 223, págs. 228-233, aquí: pág. 231. 
En un panorama general no se debe pasar por alto el fuerte elemento antiespañol en Suiza. La ciudad de Basilea era uno de los más importantes centros de la imprenta en lengua alemana, como lo demuestran las publicaciones de varios libros antiespañoles ${ }^{116}$. Si bien en Basilea se editó la Joyeuse Entrée de Felipe en Bruselas, también se imprimieron en esta ciudad del Rhin unos libelos críticos acerca de la política religiosa de Felipe II en Flandes ${ }^{117}$. En una oficina de Basilea se publicó por ejemplo una historia de las rebeliones en Flandes del historiador Adam Henricpetri ${ }^{118}$. Basilea fue la ciudad donde se imprimió una traducción alemana del Antihispanus, la primera edición de Benzoni en alemán y la muy famosa hoja volante del Signor Spaniol, que también testimonia la conexión antiespañola de la ciudad del concilio ${ }^{119}$. Se supone que el grabador era un artesano de Basilea ${ }^{120}$. Este pasquín, que se publicó entre 1571 y 1581 , resume los caracteres españoles vistos por los alemanes y suizos ${ }^{121}$. Arriba figuraban doce grabados, dibujos que venían acompañados por los versos escritos abajo. Es de suponer que esta hoja volante fue cantada por los pregoneros en los bares, fondas o plazas públicas. La primera ilustración muestra al castellano rezando en la Iglesia, pero ya la segunda imagen explica que en casa se comporta como un diablo. En la mesa, el español se parece a un lobo. Sigue el empleo de metáforas animales. En el dormitorio, el castellano se asemeja a un cerdo, convirtiendo la cámara en una pocilga -como dice el verso número cuatro-. En el quinto grabado vemos una alusión al pavo real, es decir a la vanidad del hombre hispánico. Esta hoja es sin duda alguna una de las más concisas representaciones del imaginario alemán acerca de lo español. No se menciona el nombre de Felipe II, pero está claro que los contemporáneos pensaban finalmente en el rey en El Escorial y que todos estos insultos iban dirigidos contra el monarca. Cabe señalar que también en estos grabados se representaba al español con la golilla.

\footnotetext{
GILLY, C, Spanien und der Basler Buchdruck ... (nota 66), passim.

Allerhand neuwer Zeytungen von Niderländischen Religionssachen, wie sie zu Franckfurt in der Mess dissmals feil gehaft, zusammen getruckt. Erstlich Kö. May. von Hispanien ernstliche Edict und Befelch, der exequition des Tridentinischen Consiliums. Samuel Apiarius.

118 ADAM HENRICPETRI, Niderländsicher Erstern Kriegen, Empörungen, Zweitrachten, Ursprung. anfang und end, sampt allen dem jenigen, so von König Philipps ausz Flandern inn Hispanien abschied. Basel: S. Apiarius 1575. Sobre este autor de Basilea, véase, Vermaseren, B. A., "Der Basler Geschichtsschreiber Dr. Adam Henricpetri und sein Buch für den niederländischen Aufstand gegen Spanien", Basler Zeitschrift für Geschichte und Altertumskunde, 56 (1957), págs. 35-65.

119 ELKAN, A., «Bonaventura Vulcanius und die ersten Geschichtsbücher über den niederländischen Aufstand", Oud-Holland, 24 (1906), págs. 65-76.

$1 \%$ GILLY, C., Spanien und der Basler Buchdruck ... (nota 66)), pág. 232.

21 De hecho hemos podido averiguar a través de HARMS, W. (ed.), Illustrierte Flugblätter ... (nota 98) que en el Imperio circulaba también una versión francesa.
} 
Lo que llama la atención es que apenas hay una imagen favorable de Felipe II. Contadas son las publicaciones que transmiten aspectos positivos del rex prudens, como por ejemplo con ocasión de la batalla de Lepanto ${ }^{122}$ o una refutación de la propaganda holandesa ${ }^{123}$. Uno de los pocos testimonios en forma de libelo que representa a Felipe como monarca católico es la traducción alemana de un folleto de Alonso de Castro sobre la muerte del rey ${ }^{124}$. En el propio campo católico parece que apenas existieron acciones de propaganda en favor del rey español, a no ser que procedieran de los jesuitas ${ }^{125}$. Que la corte de Madrid estaba muy molesta por las canciones y la propaganda, lo testimonia una carta de Felipe II a Maximiliano, en la cual acusa "a la gente que eran enemigos de la paz y tenían pocos remordimientos en causar estos rumores buscando su propia ventaja y la desventaja de España" (unrhuewigen fridhessigen parteiischen leuten aus lauterem neid und hass zu ihrem vorthail und unserem nachthail falschlich und boshaftiglich erdichtet) ${ }^{126}$. Felipe $/ 1$ creia además que su imagen poco favorable se debia a las actividades de los franceses. En este sentido amonestaba a su embajador en Viena, Chantonnay, del siguiente modo:

"También aveis de procurar de saber los tratos e inteligençis que los Françeses traen en Alemania para procurar de estroverselas en quanto buenamente pudieredes y avisnarnos eis [sic!] particularmente de lo que en ello huviere" ${ }^{127}$.

122 Zeittungen von dem Grossen Christen Sieg auff dem lonischen und Ausonischen Meer, widen den Türcken, so bey dem Porte Le Pante (sonsten Naupactus genandt) auss sonderbarer schickung Gittes erhalten worden ist, Den 7. Octobris 1571. Nürnberg 1571. [Bayerische Staatsbibliothek 4 Eur. 411,44] Asi como: Zeytung und bericht, Von der gantz herrlichen und seer gewaltigen Obsigung unnd Victoria, der Christlichen wicer die Türckische Armada, dergleichen hievor niemals vorgangen ist. Beshen 40 Welscher Meil, oberhalb Lepanthos, Sonntags, den 7. Octobris, dis 1571 Jars. Augsburg 1571. [Bayerische Staatsbibliothek 4 Turc. 84,30]

123 A ges, so Herr Don Fernando Aluares von Toledo. Hertzog von Alba...gefürt hat, wider Wilhalmen von Nassau, Printzen von Oranien, und Grauen Ludwigen seinen Bruder, auch gegen jhrer Cahtolischen Maiestet ndern Rebellischen und Auffrürischen im Niderland, des 1568. Jars. Dillingen 1570. [Universitätsbibliothek Tübingen Fo VI, 18.4]

124 YEPES, DIEGO DE, Christlich Gottselig Absterben Herrn Philippen des Anderen, Königen zU Hispanien. s. I. 1599 [Bayerische Staatsbibliothek München $4 \mathrm{Hom}$. 1950,11].

125 Hay que señalar que en la propaganda de la Guerra de los Treinta Años los jesuitas siempre aparecen como aliados del rey español. Lo mismo vale para el Papado, ct. ScHMIDT, P., Das spanische Imperium ...(nota 72), Cap. C. IV

${ }_{126}$ Felipe II a Maximiliano, 12 de diciembre de 1567, en, BıBL, V. (ed.), Die Korrespondenz Maximilians /I ... (nota 114), tomo 16, No 263, págs. 276-284, aquí, pág. 282

127 Instrucción de Felipe II a Chantonnay para el trato con el Emperador, 6 de septiembre de 1564, en, BıвL, V. (ed.), Die Korrespondenz Maximilian II. (nota 114), tomo 14, n²17, págs. 15-25, aquí: pág. 17. 
Dada las restricciones legales, el monarca español no podía proceder en el Imperio contra los autores de estos poemas o publicaciones. En esto tuvo que recurrir a la ayuda del Emperador que también estaba molesto de los continuos insultos ${ }^{128}$. Mi tesis es que la reacción española no consistió primordialmente en la producción de libelos y hojas volantes, sino que buscó sobre todo una respuesta recurriendo al libro ${ }^{129}$. En el siglo xVI España brilló por su producción literaria y científica. Los logros de los científicos no sólo reflejaban el progreso en las artes, sino que sus méritos recaían en el propio monarca hispánico. Para la difusión de esta producción los españoles se sirvieron con gran preferencia de los libreros e impresores de Amberes, con lo cual los volúmenes llegaban a la gran feria de Frankfurt ${ }^{130}$. Los tomos gruesos de los juristas y teólogos españoles conservados hasta hoy día en las bibliotecas alemanas atestiguan esta respuesta española a la crítica de su política y cultura. No obstante, los españoles no pagaron a sus críticos con la misma moneda. Dejaron prácticamente todo el campo de la propaganda y de la opinión pública a los protestantes, puesto que los libros y gruesos tomos - muchos de estos en latín- no llegaban sino a un público muy reducido. Los autores protestantes, por su parte, citaron en sus folletos con avidez a los autores hispánicos, criticando fuertemente las posiciones españolas.

Desde luego Madrid siempre buscó el apoyo de Viena para sus acciones en el Imperio, requiriendo del mandato del Emperador para justificar su intervención armada. Y claro está que Madrid se apoyó en su fuerte posición política y militar. Pero el rey español habilitó otro mecanismo más para influir en los centros del poder en el Imperio: Madrid se apoyó también en el sistema de sus "pensionarios". A su embajador, Felipe le encargó lo siguiente:

"Demas desto aveis de procurar de tener intelligençias en toda Alemania assi con los prinçipes nuestros nuestros amigos como los pensionarios que allí tenemos, la lista de los quales he mandado que os den con esta para saber lo que passa, y si ay algun levantamiento qie se ps dem cpm esta üara saber lo que passa, y si algun levantmiento de gente ó otra qualquier conmoçion de que pueda resultar daño á nuestro estados y tierras y aunque nos aveis de dar acá aviso particularmente dellos, la prinçipal correspondençia que aveis de tener en esto ha de ser con la duquesa de Parma mi

128 También el Emperador intervino en la Dieta de Espira de 1570 en contra de los «famos libellen», véase 3, n² 290 y n² 291, pág. 622 .

129 Schmid, . P., Das spanische Imperium ...(nota 73), Cap. E.

130 Ibidem. 
hermana y general governadora de mis estados de Flandes, á la queal aveis de avisar de todo lo que se offreçiere y supieredes" " ${ }^{131}$.

Para no perder influencia en el Imperio el rey católico no tuvo reticencias en pagar también pensiones a los estados de la Confessio Augustana ${ }^{132}$. Estas fueron las acciones de Felipe para presentar una imagen favorable. Por lo visto, la monarquía estaba mucho más interesada en mantener buenas relaciones con las cortes del Imperio que responder a la opinión pública.

Los libelos y pasquines de la Guerra de los Treinta Años, el último gran conflicto de la Contrarreforma en el cual se involucraron los españoles en Europa Central, no mencionan apenas personalmente a Felipe II. En la mayoría de los casos sólo se habla del rey español, referiéndose al monarca de Madrid como tal. Pero el público alemán, y los protestantes sobre todo, eran muy conscientes de las acciones políticas de Felipe II. En 1612 se publicó la carta de Lazarus Schwendi, que contenía severas críticas a la política felipista. Pero en el fondo se repiten los argumentos que ya se había podido escuchar en la época del Rey Prudente. Pocos años antes de estallar la Guerra de los Treinta Años el gran publicista de la teoría e historia del Imperio, Melchior Goldast von Haiminsfeld, presenta a España en su gran compilación de textos relativos al Imperio Romano-Germánico como una gran amenaza a la estructura del Reich. Se menciona a Felipe II como rey hegemónico, cuyo poder se basa sobre todo en la flota que tiene desplegada tanto en el Mediterraneo como en el Atlántico ${ }^{133}$.

Por la cantidad y densidad de las publicaciones antihispánicas - concretamente en los años 1619-21 - y por la "calidad" de los libelos, la Guerra de los Treinta Años significa, sin duda alguna, el apogeo de la «leyenda negra" en Alemania. Que no se habian olvidado los hechos ocurridos bajo

${ }_{131}$ Instrucción de Felipe II a Chantonnay para el trato con el Emperador, 6 de septiembre de 1564, en BIBL, V. (ed.), Die Korrespondenz Maximilians ... (nota 114), Tomo 14, nº 17, págs. 15-25, aquí: pág. 17.

${ }_{132}$ Una lista con los 'pensionarios' de Fellpe II en el Imperio, en WEISS, CH., (ed.), Papiers d'E. tats de Granvelle VIII, Paris 1850, págs. 182ss. Sobre este sistema de pagos, véase también, BEzOLD, F., Das Bündnisrecht der deutschen Reichsfürsten bis zum westfälischen Frieden. Bonn 1904, págs. 29ss.

133 MELCHIOR GOLdAST (ed.), Politica imperialia sive discursus politici: Acta publicata et tractatus generales. Frankfurt 1614, pág. 1150. [Bayerische Staatsbibliothek München $2{ }^{\circ}$ J.publ. g. 130] 
Felipe II lo demuestra el siguiente párrafo de un libelo, en el cual se habla del poco respeto que los españoles muestran cuando tratan con nobles y señores:

«En lo que se refiere a los nobles, ¿no es que los españoles los mataron en las Indias, en los Países Bajos, así como últimamente en Bohemia, en el Palatinado y en Portugal? Los han matado y extinguido a la manera turca. ¿Y dónde están Egmont y Horn?" ${ }^{134}$.

En esta cita, a la cual se podrian añadir muchas más, se puede ver que los acontecimientos ocurridos bajo Felipe II (la noche de San Bartolomé, la Guerra de Colonia, la acción de Aquisgrán) estaban bien presentes en la primera mitad del siglo xVII. En esta cita se refleja también la hegemonía global de Madrid, un hecho hoy dia muchas veces olvidado por los propios españoles. Pero no sólo era la propaganda en forma de libelos la que mantenía vivo el recuerdo de Felipe II. A lo largo del siglo XVII y hasta finales del siglo XVIII su imagen se transmitió también a través de las historias sobre Flandes. Tanto el belga Meteren ${ }^{135}$ como Strada, el jesuita, eran conocidos y leídos en Alemania ${ }^{136}$. Llama la atención la existencia en siglo XVII de nueve ediciones de la obra proholandesa de Meteren en alemán ${ }^{137}$, mientras que no he podido localizar edición germanohablante de la obra del jesuita Strada, que era favorable a España.

Parece que no se escribió ningún estudio por un alemán acerca de Felipe It hasta los años ochenta del siglo XVIII ${ }^{138}$. Pero con la llegada de la

134 Tommasso Campanella (atribución falsa), Librorum de Papana et de Monarchia. s.l. 1628, pág. 58.

135 EMANUEL VON METEREN, Eygentliche und vollkommene historische Beschreibung des Niederländischen Krieges I. Amsterdam 1658.

136 Famiano Strada, De bello Belgico decas duae ab excessu Caroli $V$ imp. usque ad initium praefecturae Alexandri Farnesii. Moguntiae 1651 $372-374$

Veáse, The Nacional Union Catalogue. Pre-1956 Imprints. Vol. 378. Mansell 1965. págs

138 Tampoco traen información los tres estudios que tenemos sobre la percepción alemana en el siglo XVII, BECKER-CANTARINO, B., "Die 'Schwarze Legende'. Zum Spanienbild in der deutschen Literatur des 18. Jahrhunderts", Zeitschrift für deutsche Philologie, 94 (1975), págs. 183-203; BRÜGGEMANN, W., «Die Spanienberichte des 18. und 19. Jahrhunderts und ihre Bedeutung für die Formung und Wandlung des deutschen Sparienbildes", Spanischen Forschungen der Görresgesellschaft, 1. Serie, 12 (1956), págs. 1-146; así como KLEINMANN, H.-O., “España durante la reforma ilustrada, vista descie el exterior y desde arriba. Sobre imaginología de los despachos diplomáticos". 
llustración el enfoque de la percepción de Felipe II cambió de manera profunda. Frente a la idea cada vez más dominante de la tolerancia, se llegó a condenar comportamientos intransigentes por motivos político-religiosos. Un primer hito importante en el desarrollo de la imagen de "Philipp II» lo marca la Enciclopedia de Johann Gottfried Zedler, una obra que se publicó medio siglo antes que la famosa Encyclopédie francesa. La Enciclopedia de 68 tomos fue una de las obras más influyentes en la cultura germanohablante. En un artículo sobre Felipe II nos encontramos con un monarca que en gran parte nos da la imagen del Philippus prudens ${ }^{139}$. Como expresión de esta percepción de fuerte impronta neoestoicista el Zedler asegura que en el parto su madre no quiso mostrar emociones. Felipe II nació sin que su madre hubiera dado señales de dolor y agotamiento. Esta imagen basada en las crónicas del rex prudens seguramente hace cierta justicia a Felipe II, puesto que él mismo hizo del neoestoicismo su programa ético. Siguiendo el viejo tópico de la Antigüedad su madre menciona también un sueño antes del parto: había soñado que daba a luz a un globo. Parte de esta presentación imbuida de la Estoa es el hecho de que - según este artículo- Felipe nunca se riese ni mostrase emociones ni tampoco le gustase el baile. De todos modos esta presentación de Felipe II es - teniendo en cuenta las condenas sufridas por su figura hasta esa fecha - algo positiva. En todo caso, el artículo repite una vez más las maquinaciones cometidas por el rey, pretendiendo que habia sido Felipe II quien habia presionado para el retiro de su padre. Teniendo en cuenta las circunstancias del retiro político de Carlos - las maquinaciones de Mauricio con el rey francés - esta afirmación era muy atrevida. Pero tampoco hay que olvidar que el Zedler se editó en Halle y Leipzig (Sajonia). En lo que se refiere al comportamiento del monarca, el retrato hace hincapié en la altivez y el orgullo del español, puesto que había puesto indebidamente a los príncipes alemanes. Por supuesto, el artículo habla también de la rebelión de los Países Bajos. No sólo se mencionan las advertencias críticas de Maximiliano, sino también el hecho de que Felipe II no fuera personalmente a los Países Bajos para apaciguar el conflicto. Y, ciertamente, hace mención al problema de la sucesión de Carlos, así como a la muerte del príncipe, inculpando a Felipe II. Al considerar las bases materiales de esta política, el Universal-Lexikon no se olvida de mencionar los meta-

Actas del Simposio sobre la Imagen de España en la llustración alemana 22 a 24 de mayo de 1991. Ed. por el Instituto Germano-Español de Investigacion de la Görresgesellschaft. Madrid 1991, págs. 217-235.

139 "Philipp II", en JOHANn GotTfried ZEDLER (ed.), Großes vollständiges Universal-Lexikon aller Wissenschaften und Künste. Halle/Leipzig 1732-54. 64 tomos y 4 tomos adicionales. Tomo $27 / 28$, Halle 1741 , col. 1847-1853 
les preciosos provenientes de América. Para la bibliografía el artículo remite a Meteren, a Strada y a Cabrera de Córdoba, con lo cual entraba también una voz en favor de Felipe II en las referencias. Si bien no hemos podido encontrar ninguna obra alemana sobre Felipe II desde el siglo xVI hasta 1780, lo que sí había eran traducciones: ya en 1716 se publicó el trabajo de Leti ${ }^{140}$, y en 1778 le siguió la traducción de la obra del inglés Robert Watson ${ }^{14}$.

Sin duda alguna el mayor impulso para la formación de la imagen de Felipe II en los siglos $x \mid x$ y $x x$ emana de las obras de Friedrich von Schiller. Para él, como para Johann Wolfgang von Goethe, la historia proporcionaba un material idóneo para las representaciones teatrales, para las obras dramáticas. La rebelión de las provincias holandesas que llevó a la formación de un nuevo Estado en Europa atrajo especialmente a los dos autores. En el caso de Schiller el interés le fue despertado por un amigo: el director del teatro de Mannheim, Wolfgang Heribert von Dalberg, le había proporcionado un ejemplar de Abbé Saint Real y de su Histoire de Philippe /I y le había propuesto servirse de este texto para una obra dramática ${ }^{142}$. Para Schiller, adepto de la llustración, la formación de los Países Bajos era expresión de la voluntad de libertad. El argumento atrajo a Schiller, que se puso a redactar su obra de teatro Don Carlos. Infant von Spanien, que terminó en 1784 , pero que cambió un par de veces la versión definitiva de 1805, al criticarse que había demasiados protagonistas, Felipe, Carlos, el duque de Alba, Isabel y el marqués de Posa ${ }^{143}$.

Aparte de la versión del Abbé Saint-Réal de 1691 -el dramaturgo se sirvió de la edición alemana de esta obra, publicada en 1784, en la cual se encuentra una caracterización de Felipe II por Robert Watson ${ }^{144}$-, Schiller se informó sobre Felipe II por la obra del propio Watson, el estudio de Watson sobre Carlos V, el trabajo de Leti y la obra de Seigneur de Brantô-

140 Gregorio Len, Leben und Thaten Philipps des Anderen Königs von Spanien. 2 tomos. Leipzig 1716.

141 Robert Watson, Geschichte der Regierung Philipps des Zweyten. König von Spanien. 2 tomos. Lübeck 1778 .

:a2 AcOSTA, L. "Introducción», en FRIEDRICH von SchIllef, don Carlos. Infante de España Traducción de Fernando Magallanes. Madrid 1996, págs. 9-117, aquí: 50-63.

143 Los cambios se debieron al hecho de que la obra no fue saludada con unanimidad. Habia una rivalidad entre los personajes. y el papel y el protagonismo de don Carlos sucumbieron a varias remodelaciones, cf. Friedrich von Schiller, Don Carlos. Dramen II. Ibid. Werke und Briefe, los comentarios, págs. 1057 ss. Como introducción, vale también, PORNBACHER, K. (ed.), Friedrich SchiHer. don Carios. Erläuterungen und Dokumente. Stuttgart 1973.

144 Abbé SaInt-RÉal, Geschichte des spanischen Prinzen don Carlos. Eisenach: Johann George Ernst Wittekind 1784, págs. 512-514. 
me, en la cual el autor francés da una visión no del todo negativa ${ }^{145}$. Contó además con una traducción al alemán de la historia de Juan de Ferreras, con lo cual tuvo a su disposición una obra en forma de anales y de tendencia profelipista ${ }^{146}$.

En esta obra, Schiller dibujó la imagen de un Don Carlos frustrado por su padre. La frustración es tanto personal -porque el padre se casa con la novia que originalmente estaba prevista para el príncipe de Asturias y el Infante siente celos hacia su padre-como política; en razón del desacuerdo sobre la política en Flandes. Toda la presentación de la corte española se convierte en la descripción de un baluarte del despotismo. Isabel, la reina venida de Francia, sufre por la atmósfera fría y tiene anhelos de su patria. Sólo el marqués de Posa habla de una manera franca con el rey. Al presentar una visión más libre de la política y del mundo, el monarca le ataca: "Sois un protestante" (Acto tercero, décima escena). Felipe, a su vez, no cede a ruegos de su hijo pidiéndole el favor de encargarle una misión política: la de ser gobernador de Flandes. Para este puesto Felipe había destinado a Alba - el público alemán estaba muy bien enterado de quién era Alba. Finalmente se procede al arresto del infante y se da a entender que Felipe II fue responsable de la muerte de su hijo.

Para el protestante Schiller Felipe II no era sino un tirano, palabra que utiliza el marqués de Posa en un encuentro con el Rey, a quien dice además que había impuesto el silencio del cementerio en su imperio. Posa era un simpatizante de los flamencos en su lucha contra el rey español, una figura que representaba el impetu ilustrado por la libertad. Tanto el marqués de Posa como don Carlos se pronuncian y luchan en favor de la libertad. El que se opone - Felipe II- forzosamente goza de poco prestigio ante el escritor y su público ilustrado, que aspiraba en la propia Alemania a más libertades y derechos ciudadanos. Desde la perspectiva ilustrada la política religiosa cambia de connotación. Ya no se trata de una medida de persecución de los otros, sino que se juzga como símbolo de intolerancia. Se convierte ahora en un acto de fanatismo y de oscurantismo. La intolerancia de Felipe II es a finales del siglo XVIII la gran acusación en contra de su persona y su política. Luego Schiller mismo se dio cuenta de que había idealizado a don Carlos, porque - por

\footnotetext{
145 "Philippe II, Roy d'Espagne", en Seigneur dE Brantôme, Ouevres complètes. 5 tomos. Den Haag 1740, 5 tomos. tomo $V$, págs. 97-128. Además hay un retrato de don Carlos, págs. 128 138.

146 Johann von Ferreras, Allgemeine Historie von Spanien mit den Zusätzen der französis chen Üebersetzung neben der Fortsetzung bis auf gegenwärtige Zeit. Tomos 9 y 10 . Halle 175860 .
} 
lo visto- comenzó a dudar de la voluntad política y de la capacidad mental del infante ${ }^{147}$.

Pero Schiller, que comenzó a interesarse más en la separación de los Países Bajos y que acabó por ocupar una cátedra en la universidad de Jena, compuso poco tiempo después una obra histórica sobre La separación de los Paises Bajos del gobierno español (Der Abfall der Niederlande von der spanischen Krone), estudio en el cual hizo otra vez hincapié en la aspiración a la libertad ${ }^{148}$. Schiller profundizó en sus conocimientos de la historia del siglo xvi. Ya con la primera versión de su Don Carlos había editado - sin indicar su nombre como traductor- el retrato que Sebastian Mercier había realizado de Felipe II ${ }^{149}$. Entre la bibliografía se encuentran los autores Jacques Auguste de Thou (Thanus) ${ }^{150}$, Strada, y Jan Wagenaar ${ }^{151}$, así como la Apología de Guillermo de Orange. La imagen de Felipe II quedó intocada. Los holandeses son para Schiller los grandes protagonistas, los que anhelan la libertad. Schiller les reconoce una lucha y una voluntad heroicas e idealiza su combate como audaz, brillante y emocionante ${ }^{152}$.

"Grande y apaciguadora es la idea de que las presunciones del poder del principe fracasan ante la libertad...” ${ }^{153}$.

La imagen negativa de Felipe II como rey tirano e intolerante se refleja sobre todo al contrastar el personaje del rey con las provincias que heredaba. En la obra, ya en el primer libro, hay un retrato del rey y de las provincias. Estas eran presentadas como opulentas, ricas y caracterizadas por el bienestar ${ }^{154}$. Además Schiller contrasta la autoridad de Carlos $\mathrm{V}$ con el despotismo del hijo, quien con su política arruina el comercio y la riqueza de Flandes.

147 Koch, H., Schiller und Spanien. Münchener Romanistische Arbeiten. Heft 31. München 1973, págs. $72 \mathrm{~s}$.

${ }_{148}$ En lo que se refiere a Schiller como historiador, véase el tomo de DANN, O./ OELLERS, N./ Osterkamp, E. (eds.), Schiller als Historiker. Stuttgart 1995, Especialmente, Schul IN, E. «Schillers Interesse an der Aufstandsgeschichte", en el mismo tomo, págs. 137-148.

149 Sebastian Mercier, Philipp der Zweite, König von Spanien, en Friedrich von Schiller, Sämtliche Werke. Band IV: Historische Schriften. München 1982, págs. 935-953.

150 JAC. AUG. THUANUS, Historiarum superioris seculi pars prima. Frankfurt 1714.

151 JAN WAGENAAR, Allgemeine Geschichte der vereinigten Niederlanden, aus dem Holländischen übersetzt. 3 tomos. Leipzig 1756-58.

152 FRIEDRICH VON SCHILLER, Geschichte des Abfalls der Vereinigten Niederlande von der spa nischen Regierung. Sämtliche Werke. Band IV: Historische Schriften. München 1972, pág. 1.

153 Ibidem.

154 Op. cit., págs. 47-53, aquí pág. 49 
"Dos conceptos, su ego, y lo que estaba encima de su ego, determinaron su espiritu. Egoísmo y religión eran el contenido y lema de su espiritu pobre. Era rey y era cristiano, pero las dos cosas lo era de manera mala, porque queria reunir los dos elementos... Su fe era cruel y siniestra, porque su Dios era un ser cruel» ${ }^{155}$.

Pero también matiza diciendo que Felipe tenía efectivamente temor de Dios. Por eso, comparándolo con su padre («Carlos era un bárbaro por reflexión»), Felipe era un bárbaro "por pasión». Carlos era un monarca ilustrado y fuerte, Felipe era una cabeza más limitada y más debil, pero -dice Schiller - tal vez, en este sentido, "era más justo" ${ }^{156}$. La razón de este defecto personal residía - según el catedrático de Jena- en la grandeza de la monarquia, que exigia fuerzas sobrehumanas y que era una tentación demasiado grande para el "orgullo humano". Además Schiller explica el despotismo por la falta de inteligencia:

"Felipe tenía que ser más déspota que su padre, porque su mente era más estrecha. En otras palabras tuvo que ajustarse de manera más estricta a las reglas generales... Felipe II no tenia objetivo más importante que la uniformidad de la fe y de las leyes, porque sin éstas no podía gobernar» ${ }^{157}$.

También en la otra gran obra histórica de Schiller — La historia de la Guerra de los Treinta Años- se habla de Felipe II. Al reflexionar sobre los orígenes de esta guerra tan decisiva para la historia de Alemania, Schiller toma como punto de partida la introducción de la reforma de Lutero. Para él, el luteranismo, la Reforma, era un acontecimiento grande y memorable, del cual se deducian todos los demás desarrollos y perspectivas entre 1517 y 1648. Así, si en el primer párrafo del libro hace hincapié en la importancia de este hecho religioso-político, en el segundo trata de los enemigos del protestantismo. No asombra entonces que se dedique a Felipe II:

"La Reforma hizo a los holandeses insoportable el yugo español, y reveló en ellos el valor y el deseo de quebrar ese yugo, porque en ella encontraron las fuerzas. Todo lo malo que Felipe 11 emprendió contra Isabel de Inglaterra, era en venganza por la protección que ésta reina les habia ofrecido, y porque ella se habia puesto a la cabeza del partido religioso que él intentaba machacar" ${ }^{158}$.

155 Op. cit., pág. 51.

155 Op. cit., pág. 51.

157 Op. cit., pág. 52.

158 FrIEDRICH VON SCHILlER, Geschichte des Dreissigjährigen Krieges. Ibid. Sämtliche Werke. Band IV: Historische Schriften. München 1982, p. 351 (= la primera página). 
Johann Wolfgang von Goethe, otro gran clásico de las letras germánicas de finales del siglo XVIII y de comienzos del Xix, compartió el interés del poeta Schiller por la historia. En este sentido se mostró igualmente fascinado por la formación de un nuevo Estado en la Europa del siglo XVI. El hecho de que los vecinos del noroeste hubieran lanzado un reto al rey más potente de la época, atrajo al poeta y ministro de Sajonia-Weimar. Pero Goethe juzgó la resistencia holandesa desde otra perspectiva. No se concentra en el drama personal de Felipe II con su hijo, sino que presta más atención al conflicto político dentro del mundo de los nobles, tomando al conde de Egmont como protagonista y dando su nombre a la obra drámatica: Egmont. Si bien Goethe sintoniza en gran medida con la imagen negativa de Felipe como tirano, como intolerante, hay en la obra Egmont un matiz importante. Felipe, aunque fuera un monarca autoritario, es considerado por Goethe como modernizador. Dirigiéndose a Alba (cuarto acto), Egmont critica la intención de Felipe II de uniformizar el país. En contra de la política de Madrid Egmont defiende los derechos tradicionales, las libertades antiguas. Con esto Goethe expresa sus reticencias al absolutismo ilustrado con su ímpetu unificador y controlador de todo. Como ministro de un pequeño Estado, Goethe vivía de cerca la tendencia de volver cada vez más uniforme la vida política y social mediante el absolutismo ilustrado. Ya se habian articulado las primeras voces conservadoras, como Justus Möser, en contra de este supuesto "progreso" unificador. Así, el Emperador José II fracasaría con sus reformas centralizadoras en los años 1787/88 en Bélgica, al rebelarse el pueblo contra sus pretensiones centralistas.

Esta postura crítica frente al absolutismo modernizador se detecta en el siguiente diálogo de Egmont:

«VANSEN: ...¿No tiene que ser juzgado por sus leyes y derechos? ¿No es cierto?

UN VECINO/UN CIUDADANO: En efecto.

VANSEN: Un vecino de Bruselas, ¿no debe tener leyes diferentes a uno de Amberes? ¿Y uno de Amberes leyes distintas a un vecino de Gante? ¿Puede ser de otra forma?» ${ }^{159}$.

Goethe, que vio la similitud entre las protestas de los años ochenta del siglo XVI y del XVIII, se hizo entonces eco de las críticas al absolutismo

159 Johann WolfGang Goethe, Egmont, en Ibid. Dramen 1776-1790. Sämtliche Werke, Briefe, Tagebücher und Gespräche, I. Abteilung, Band 5, págs. $483 \mathrm{~s}$ 
ilustrado. Felipe $1 /$ era en este sentido un renovador, un símbolo del absolutismo, contra el cual se había formado la oposición en Alemania y en otros países, por temor a la uniformidad de la vida ${ }^{160}$. Goethe simpatizó con Egmont, no tanto por su lucha en favor de la libertad absoluta, sino por su afán de conservar el mundo tradicional en clara oposición a la intención inicial de Schiller, aunque Schiller tampoco era del todo simpatizante de las últimas consecuencias de la llustración ${ }^{161}$.

Goethe influyó en el Egmont de Beethoven. Pero muchísima más repercusión tuvo en el público alemán en general y en los historiadores en particular la obra schilleriana de Don Carlos. Con su tragedia Schiller no sólo trató el problema puramente religioso-político, sino que atrajo al público por el problema personal del monarca: la relación con su propio hijo. Ningún otro enfoque pareció más propicio para indagar la propia personalidad del rey, su doble calidad de padre y hombre. Por lo tanto, la obra de teatro Don Carlos - no obstante sus varias remodelaciones- gozó de un gran renombre y fue ampliamente conocida. Una repercusión inmediata de la obra historiográfica de Schiller la vemos al consultar la historia del cátedratico de Gotinga Arnold H. L. Heeren. Este historiador, que estaba muy interesado en la historia de las potencias marítimas y la expansión europea, ${ }^{162}$ compuso una historia general, en la cual trataba también de la separación de los $\mathrm{Pa}$ íses Bajos. En ella calificaba a Felipe II de cruel y despótico, aunque reivindicaba que había que juzgar a Felipe según su propios principios ${ }^{163}$. Una vez más vemos la herencia de los siglos XVI y XVII. Heeren remite, en lo que a la bibliografía se refiere, a Meteren, a Strada y a Schiller.

Una de las primeras disertaciones sobre don Carlos y el carácter de Felipe II desde el punto de vista historiográfico la debemos a Leopold von Ranke ${ }^{164}$. Ranke confiaba mucho en las relaciones de los embajadores ita-

160 BORCHMEYER, D., “Der aufgeklärter Herrscher im Spiegel von Goethes Schauspiel», en $\mathrm{B}_{\mathrm{IRTSCH}}, \mathrm{G}$. (ed.), Der Idealtyp des aufgeklärten Herrschers. Autklärung, 2 (1987), págs. 49-74. IDEM, “Goethes und Schillers Sicht der niederländischen Revolution», en DANN, O. ET AL. (eds.), Schiller als Historiker (nota 148), págs. 149-155.

161 SCHULIN, “Schillers Interesse»... (nota 148), pág. 142.

162 En torno a su obra historiogrática, véase, SEIER, H., "Arnold Herrmann Ludwig Heeren», en WEHLER, H.-U. (ed.), Deutsche Historiker IX. Göttingen 1982, págs. 61-80.

163 ARnold H. HeEREN, Historische Werke. 15 tomos. 8. Theil. Göttingen 1821-26, [Reimpresión Frankfurt a. M. 1987] pág. 99-124.

164 Cf. la caracteristica de su obra BERDIng, H., "Leopold von Ranke", en WEHLER, H.-U. (ed.), Deutsche Historiker I. Göttingen 1971, págs. 7-24. 
lianos, especialmente los venecianos. Aprovechando esta documentación se dedicó ya en 1829 a la figura del príncipe don Carlos, y por lo tanto a la de su padre ${ }^{165}$. De todas formas Ranke desmiente que Felipe II hiciera matar a su hijo, sino que éste murió por haberse descuidado totalmente. Luego, en otro artículo, Ranke llegó a la conclusión de que existió efectivamente un conflicto político entre el rey y el príncipe, pero la naturaleza un poco desordenada de Carlos impidió el desarrollo de un auténtico y grave conflicto entre los dos ${ }^{166}$. El resultado de la investigación de Ranke es importantísimo, porque hasta esa fecha se creía que Felipe II era responsable de la muerte de su hijo. Ranke, una autoridad del mundo protestante y prusiano, refuta esta acusación. Sintoniza entonces con una opinión que en el campo de los españoles ya se había difundido desde la crónica de Cabrera de Córdoba.

Pero la evaluación de la figura de Felipe II en la obra rankiana no para ahí. En su Historia de los otomanos y la monarquía española en los siglos $x V I y X V I I$, este protestante, hijo de un pastor, nos da un retrato muy intuitivo del rey. De acuerdo con su metodología del Historismus, Ranke trata de "comprender» la motivación de Felipe II desde dentro. Por lo tanto dice que Felipe II intentó estar siempre bien enterado de los sucesos en su reino. Le importa la religión, y Ranke alaba el sentido trabajador del monarca. También subraya este rasgo neoestoicista, al describir la actitud del rey en momentos difíciles: guardar la tranquilidad y encontrar el sosiego ${ }^{167}$.

De acuerdo con la cultura historiográfica del siglo xIX y bajo la fuerte influencia del positivismo se constituyeron grandes colecciones de fuentes inéditas. El austríaco Matthias Koch se lanzó a la edición de la correspondencia del Emperador, que contenía muchas cartas del embajador de Viena en Madrid, Adam von Dietrichstein ${ }^{168}$. Dietrichstein habla del príncipe en dos cartas famosas: en la primera dice que, según los rumores, sufría de muy mala salud física y mental. Luego en otra carta, al haber conocido personalmente al príncipe, parece rectificar un poco su opinión. Según Koch, muchas cartas revelan la preocupación de la corte por la salud física y mental del sucesor y de una manera muy drástica llega a la conclusión siguiente: personas como don Carlos merecen el manicomio,

165 Ranke, L. V., "Zur Geschichte des Don Carlos", Jahrbücher der Literatur, 46 (Wien 1829), págs. 227-266.

166 Hay una versión corregida de 1877, pero a grandes rasgos mantiene la misma interpretación, IDEM, "Don Carlos Prinz von Asturien, Sohn König Philipps II. von Spanien", en IDEM, Gestalten der Geschichte. Savonarola. Don Carlos. Wallenstein. Berlin, Darmstadt 1954, págs. 117-195.

167 Ranke, L. V., Die Osmanen und die spanische Monarchie im 16. und 17. Jahrhundert. Sämmtliche Werke. Band 36. 4. ed. Berlin 1877, págs. 97-109.

168 MATTHIAS KOCH (ed.), Quellen zur Geschichte des Kaisers Maximilian II in Archiven gesammelt und erläutert. 2 tomos. Leipzig 1857-61. 
pero no el trono ${ }^{169}$. En un largo artículo Adolf Helfferich subrayó también el precario estado psíquico del príncipe de Asturias ${ }^{170}$.

Junto con los hallazgos archivísticos de Gachard ${ }^{171}$, que confirmó la tesis de Ranke, pero que subrayó a la vez el carácter frío y severo de Felipe, los historiadores de lengua alemana discutieron los nuevos resultados ${ }^{172}$. El debate en torno a don Carlos cobró un verdadero auge en los años sesenta y la problemática dejó correr mucha tinta. En un artículo donde resuena la obra schilleriana, Wilhelm Maurenbrecher, un historiador protestante, tomó al principio una posición confirmando la voluntad política de don Carlos y la posibilidad de que Felipe II hiciera matar a su hijo ${ }^{173}$. Pero luego, poco a poco, fue rectificando su postura, interpretando las relaciones de Dietrichstein -y los informes a la corte de Viena ${ }^{174}$ — como claras pruebas de la incapacidad intelectual de Carlos ${ }^{175}$.

Maurenbrecher no quedó sin críticos. Alfred Schmidt, historiador de Jena, la universidad donde había enseñado Schiller, se prestó a defender la imagen que había forjado el poeta clásico alemán. En 1874 editó un libro con un ensayo sobre el Rey Prudente y su hijo ${ }^{176}$. Según Schmidt, sobre todo el segundo informe de Dietrichstein ${ }^{177}$ revela que don Carlos si fue totalmente capaz de desarrollar ideas propias y políticas y que existió un conflicto con el padre severo y frío, que Felipe trató de resolver matando al hijo ${ }^{178}$. Como consecuencia la imagen de Felipe II volvía a ser poco halagüeña:

169 Ibidem, tomo II, pág. 222.

170 ADOLF HELFFERICH, "Don Carlos von Spanien", Raumers Historisches Taschenbuch 2. ser. 10 (1859), págs. 1-105, aquí: págs. 51ss.

17. LouIs GaChard, Don Carlos et Philippe II. 2 Tomos. Bruxelles 1863

172 Un resumen muy breve da BAUCH, R. v., "Nachwort", en GIARDINI, C. (ed.), Don Carlos. In fant von Spanien 1545-1568. 2. Ed., München 1986, págs. 252-284. Muy buen resumen (hasta 1915) en BIBL, V., "Die Don-Carlos-Frage", Mitteilungen des Instituts für Österreiche Geschichtsforschung [citado en adelante MIÖG] 36 (1915), págs. 448-496

173 Wilhelm MaURENBRECHER, "Don Carlos", HZ 11 (1864), págs. 277-315.

174 WILHELM MAURENBRECHER, "Beiträge zur Geschichte Maximilians II. 1548-1562", HZ 32 (1874), págs. 221-297, donde cita en pág. 289 una carta encontrada en el Haus-, Hof- und Staatsarchiv de Viena, donde el encargado del Emperador pidió una explicación del atraso en las negociaciones matrimoniales de Carlos con la infanta Ana de Austria, la hija del Emperador Maximiliano II.

175 WiLHELM MAURENBRECHER, "Don Carlos. Vortrag gehalten in Dorpat am 11. März 1868", en VIRCHOW, R. /HOLTZENDORFF, Fr. V. (eds.), Sammlung gemeinverständlicher wissenschaftlicher Vorträge. 4. Serie, H. 73-96 (Berlin 1969), págs. 679-710.

176 SCHMIDT, A., "Don Carlos und Philipp II.", en, IDEM, Epochen und Katastrophen. Berlin 1874, págs. 251-385.

177 Dietrichstein, 29. Juni 1564, en KoCH, M. (ed.), Quellen zur Geschichte ... (nota 168), tomo 1, págs. 127-129.

178 Wilhelm Maurenbrecher, “Besprechung des Aufsatzes 'Don Carlos und Philipp II.' von SCHMIDT, A. in dessen Buch: 'Epochen und Katastrophen', Berlin 1874», Jenaer Literaturzeitung, 1, 40 (1874), págs. 626-628. 
"Desgraciadamente es cierto que los secretos, la hipocresía y las mentiras fueron las características que dominaron todo en Felipe II, su gabinete y los círcuios más íntimos de sus cortesanos $* 179$.

Maurenbrecher, quien entretanto había cambiado de opinión, replicó que Schmidt había interpretado mal los informes y por eso negaba la precaria condición mental del príncipe, acusación que Schmidt rechazó ${ }^{180}$. De cierta manera la intervención de Schmidt significó un paso hacia atrás respecto a los resultados de Ranke, Koch y Gachard.

Claro está que Schmidt mencionó - como prácticamente todos - a Schiller para garantizar el interés por su obra. Pero introdujo otro factor más para atraer al lector por la problemática de don Carlos. Evocó el conflicto entre el futuro rey Federico II de Prusia y su padre Federico Guillermo, una dura lucha en la casa de Hohenzollern que también tuvo como momento culminante la encarcelación del futuro monarca. Federico estaba imbuido de la idea de la tolerancia y se rebeló contra la severidad del padre. Hay otro factor más a tener en cuenta, aunque los debates no se refieren explicitamente a este tema: las consecuencias de la unificación alemana (1870-71), una problemática que desde luego dominó la historiografía mucho más que el tema de don Carlos. Alemania vivía su unificación nacional, que intelectualmente venía acompañada por las discusiones acerca de las causas de la tardía unidad nacional. En vista del ultramontanismo católico, los protestantes afirmaron que sin Lutero no se hubiera producido la unificación alemana. Al fin y al cabo fue Prusia, la potencia protestante, la que forzó la unidad de los alemanes. Este debate intelectual vino acompañado por una fuerte contienda política de Bismarck en torno a la lealtad de los católicos en el Deutsche Reich (Kulturkampf), que se desarrolló inmediatamente después de la unificación. Para el mundo católico esto significó a la vez una seria amenaza y un reto, puesto que tan sólo una tercera parte de los alemanes eran católicos ${ }^{181}$. La cultura católica se sintió en cierta medida a la defensiva en los años setenta y ochenta ${ }^{182}$. Aunque los artículos no siempre se refieren a este hecho, hay que tenerlo en cuenta como trasfondo.

179 Schmidt, A., “Don Carlos ..." (nota 176), pág. 254.

180 SCHMIDT, A., "Erwiderung auf Herrn Maurenbrecher's Besprechung meiner Arbeit über 'Don Carlos' in No 40 der 'Jenaer Literaturzeitung'", Jenaer Literaturzeitung 1, No 51(1874), Beilage, págs. 1-12. Maurenbrecher, a su vez, repitió su posición rectificada en IDEM, "Historische Studien über Don Carlos", Die Grenzboten. Zeitschrift für Politik, Literatur und Kunst 33 (Leipzig 1874), II. Semester, 1. Bd., págs. 241-255 y 281-293.

181 NiPPERDEY, TH, Deutsche Geschichte 1866-1918. Tomo 11: Machtstaat vor der Demokratie. München 1992, pág. 366.

182 Ibidem, págs. 366ss 
Pero la cuestión en torno al hijo no se acalló. Reinhold Baumstark, un protestante convertido al catolicismo, defendió a Felipe II en el sentido católico; quería hacerle justicia ${ }^{183}$. Según Baumstark, el pueblo español apoyó las actividades de la Inquisición. Sostuvo además que el rey había tenido unos principios sólidos, lo cual no era ningún defecto moral. Como la mayoría de los autores modernos, Baumstark nos describe un monarca con ademanes estoicos. Pero en un punto comparte la misma opinión que Schiller: intelectualmente calificaba a Felipe II como inferior a su padre ${ }^{184}$. Aunque los alemanes alrededor de 1870 estuvieran concentrados en averiguar las causas y orígenes de su tardía formación como Estado nacional, la problemática de don Carlos por sus aspectos culturales cuajó muy bien en las tendencias espirituales de aquellos años.

Simultáneamente a los debates acerca de la culpabilidad y de la "calidad moral» de Felipe II como padre y monarca, se estableció un nuevo enfoque en la evaluación del Rey Prudente. Se intentó comprender mejor sus acciones y juzgarlo desde su propio punto de vista. Claro está que este concepto de «entender» emana de la influencia de Ranke, quien describe ya en un tono mucho más neutro y menos polémico las metas y principios políticos de Felipe. Un paso muy importante en este sentido es la aplicación del concepto de absolutismo. Con la aplicación del absolutismo a Felipe, el monarca español ya no estaba tan alejado de los otros señores alemanes de la época, puesto que todos anhelaban ejercer un régimen monocrático. Con esta caracterización política Felipe II ganó aún cierto rol de protagonista, ya que Reinhold Koser en un artículo clásico sobre la formación del absolutismo calificó el régimen de Felipe como absolutismo confesional ${ }^{185}$. Mientras Felipe II era considerado como soberano absoluto, Koser advertía que en Aragón el monarca español había respetado concienzudamente la constitución ${ }^{186}$. Con este protagonismo se aclaró un poco la imagen de Felipe, puesto que su intención política había sido compartida por los príncipes alemanes.

Al comienzo de nuestro siglo el debate en torno a don Carlos tampoco se acalló. En Austria se siguió discutiendo el problema del príncipe español

\footnotetext{
ig3 Reinholo Baumstark, Philipp II. ... (nota 8).

184 Op. cit., pág. 15.

185 REINHOLD KOSEA, "Die Epochen der absoluten Monarchie in der neueren Geschichte [1889]», en HUBatSCH, W. (ed.), Absolutismus. Darmstadt 1973, págs. 1-64, aqui: pág. 1. Ya antes Leopold August Warnkönig, Don Carlos. Leben, Verhaftung und Tod dieses Prinzen. Nach den neuesten Biographien und mit Rücksicht auf frühere Forschungen bearbeitet. Stuttgart 1864, habia hecho hincapié en el régimen absolutista de Felipe II, disculpando así los "defectos y de la mala fama" del rey español, esp. págs. 77-79, aunque se mantiene con todo muy crítico con Felipe.

196 KOSER, R., "Die Epochen” (nota 185), pág. 9.
} 
en un momento muy dramático de la historia de este país. Después de la unificación alemana sin Austria (Kleindeutsche Lösung), se emprendió una indagación sobre las raíces de la monarquía habsburguesa. Se cuestionó el futuro de una monarquía multiétnica frente a la victoria inminente del nacionalismo ${ }^{187}$. Para los austríacos el debate sobre el príncipe de Asturias tenía especial interés, porque Felipe II había pedido el envío de los dos archiduques Ernesto y Rodolfo para educarlos en España, y posiblemente, hacer a uno de los dos heredero de su trono y de un imperio ${ }^{188}$. Pero además existía un paralelo muy dramático: la propia monarquía autríaca que se había visto afectada por un severo problema de sucesión: el suicidio del Kronprinz y Erzherzog Rodolfo. Rodolfo, el presunto sucesor al trono, había simpatizado con los liberales, con los nacionalistas y con los húngaros. Había tenido, asimismo, discusiones políticas con su padre el legendario Emperador austríaco Francisco José. Pero -igual que don Carlos-habia sufrido de melancolías y de problemas mentales. Luego se había suicidado en enero de 1889 junto con su amante. Pero otro paralelismo era aún más espectacular: los críticos de la monarquía del Danubio compararon la reacción fría y ensimismada de Franciso José I ante la noticia de la muerte de su hijo con la del rey prudente cuando murió don Carlos ${ }^{189}$. Fue en estas circunstancias cuando Max Büdinger publicó su obra sobre la muerte del príncipe español ${ }^{190}$. El libro no tenía mucha originalidad, sino que repetía los argumentos ya conocidos. Su intención era, sobre todo, la de subrayar la importancia de las crónicas de la Casa de Austria, singularmente la de Cabrera de Córdoba.

El debate austríaco cobró nuevo impulso por un artículo de Anton Chroust, en el cual se destacaba la existencia de relaciones francesas de comienzos del siglo Xix sobre la apertura del sepulcro en 1795, según las cuales, al abrirlo, Carlos fue encontrado decapitado ${ }^{191}$. Este hallazgo provocó inmediatamente un debate sobre la muerte de don Carlos. El artículo de Chroust fue el punto de partida para la obra sobre el príncipe de Viktor Bibl, que ya había editado la correspondencia de Maximiliano, dos tomos en los cuales también figuraban documentos en torno a la salud de don Carlos. Luego Bibl, quien en general goza del renombre de haberse con-

187 AlPhONS Lhotskr, Österreichische Historiographie. München 1962, págs. 198-206.

189 Victor BiBl, "Die Don-Carlos-Frage" (nota 172), págs. 463ss.

189 Adam Wandruszka, Das Haus Habsburg. Die Geschichte einer europäischen Dynastie. 2 ed., Wien, Freiburg, Basel 1978, págs. 118-128.

190 Max Budinger, Don Carlos' Haft und Tod insbesondere nach den Auffassungen seiner Familie. Wien und Leipzig 1891.

191 ANTON Chroust, "Der Tod des Don Carlos". MIÖG 35 (1914), págs. 484-494. 
vertido en un autor algo sensacionalista ${ }^{192}$, tocó este tema, poniendo en entredicho la personalidad de Felipe $1{ }^{193}$, presentando una imagen de Felipe II que parecia una vuelta a las descripciones schillerianas de un siglo atrás. Por lo tanto, su compilación fue duramente criticada ${ }^{194}$. La postura algo escandalosa de Bibl provocó una última respuesta de parte de Felix Rachfahl, un representante de la "Ranke-Renaissance". Rachfahl defiende a Felipe II en contra de las acusaciones de Schiller, Schmidt y Bibl, aunque marca su distanciamiento en lo que se refiere al papel de padre tierno y amable. Con el protestante Felix Rachfahl nos hallamos ante un último intento de resumir los resultados en torno a don Carlos. Rachfahl hace hincapié en la anormalidad del joven Carlos dando mordiscos a sus amas ${ }^{195}$. Además, Rachfahl atestigua a don Carlos una falta de disciplina y de constancia en sus emociones ${ }^{196}$. Según su parecer, la personalidad variable de Carlos significó una gran amenaza para el porvenir de la monarquía ${ }^{197}$.

De acuerdo con el neorankismo y prácticamente al final de la época imperialista - para los alemanes - se vislumbra una nueva faceta de la imagen felipista. Con la caída de la Großmachtpolitik alemana el monarca español se interesó ahora también por haber sido señor de un imperio. Para Erich Marcks, seguidor de la escuela de Ranke ${ }^{198}$, el rey de El Escorial tenía un atractivo particular por ser un objeto de estudios para los problemas de índole política y diplomática. Marcks, que se dedicó también a Inglaterra y su imperio, compara a Felipe con el zar del siglo XIX -ambos dominaron Europa desde el borde del continente ${ }^{199}$ - , haciéndose así eco de la rusofobia de la época. En cuanto a la caracterización de la personalidad real, repite el esquema de percepción ya conocido. El Escorial es --según este historiador de Múnich- el reflejo de la mentalidad española: grande, pesado, uniforme y mudo. El edificio al pie de la Sierra de Guadarrama es para Marcks un enorme palacio monacal ${ }^{200}$. Ve a Felipe II como la araña de El Escorial, que lo gobernaba todo, pero con gran lentitud y muchísimas veces con reacciones

192 ALFONS LHOTSKY, Geschichte des Instituts für Österreichische Geschichtsforschung 18541954. MIÖG. Ergänzungsband XVII. Graz, Köln 1954, pág. 275, n. 61.

193 Viktor Bibl, Der Tod des Don Carlos. Wien, Leipzig 1918.

194 Reseña de EHSES, St. en, Historisches Jahrbuch 40 (1920), págs. 256-260.

195 Felix Rachfaht, Don Carlos. Kritische Untersuchungen. Freiburg i. Br. 1921, pág. 14

196 Op. cit., pág. 26-31.

197 Op. cit., pág. 31

198 KRItL, H.-H., Die Ranke-Renaissance. Max Lenz und Erich Marcks. Ein Beitrag zum historischpolitischen Denken in Deutschland 1880-1935. Berlin 1962, esp. págs. 60-66. WEBER, W., Die Priester der Klio. Historisch-sozialwissenschaftliche Studien zur Herkunft und Karriere deutscher Historiker und zur Geschichte der Geschichtswissenschaft 1800-1970. Frankfurt a. M., 2. ed. 1987, pág. 253.

199 MARCKS, E., «Philipp II» (nota 8), págs. 561-591, aquí: pág. 572.

200 Op. cit., pág. 563. 
demasiado tardías ${ }^{201}$. En lo que se refiere a su capacidad intelectual, Marcks juzga a Felipe II inferior a su padre. Felipe cometió muchos errores personales y no disponía de suficiente fuerza y voluntad ${ }^{202}$. Con su sentido del deber y del trabajo el rey disimuló su insuficiente capacidad intelectual ${ }^{203}$. Refuta la idea de un conflicto político con don Carlos, haciendo hincapié en que el rey pudo ser muy tierno y amable, por ejemplo, en el trato con su personal en la corte y en las cartas con sus hijas ${ }^{204}$.

Al cuestionar la base de la política hegemónica de Felipe II, Marcks subraya la unidad en la fe -herencia de la España medieval cristiana que había luchado contra los musulmanes-y el hecho de que los españoles eran un pueblo de soldados ${ }^{205}$-, en lo que vemos un largo reflejo de los pasquines del siglo XVI. Todos estos valores se reunían en su monarca: «Felipe simbolizó este pueblo: llegó a ser su expresión» ${ }^{206}$. La condición incuestionable para el ejercicio del poder era la unidad española, tan cara a Felipe. En un apartado Marcks se dedica al análisis del fracaso de la hegemonia - un problema muy candente a comienzos de los años veinte de nuestro siglo-. Según Marcks, España dirigió toda su fuerza a la conquista de otros territorios, sin cuidar suficientemente su propia cultura. Además, la expansión se hizo tan rápidamente que la carga fiscal sofocó los recursos españoles. No obstante, remite al florecimiento cultural, al cual Felipe allanó el camino. Con su interpretación Marcks ayudó a fomentar una imagen según la cual España había cesado de ser una potencia hegemónica en Europa después de la muerte de Felipe II --si bien Marcks no lo expresó tan tajantemente-, una interpretación muy difundida en Alemania hasta los años setenta. Al abordar la cuestión de la decadencia española, menosprecia claramente los factores económicos, a los cuales apenas presta atencíon ${ }^{207 .}$

Ningún autor de lengua alemana dedicó tanto esfuerzo y esmero en presentar una imagen positiva de Felipe II como Ludwig Pfand ${ }^{208}$. Hasta 1979 se habían publicado ocho ediciones de su libro que sufre, sin embargo, en

Op. cit., pág. 564.
Op. cit., pág. 590 .
En otro articulo sobre Felipe II se expresaba en el mismo sentido, MARCKS, E., “König Philipp II. von Spanien", en IDEM, Männer und Zeiten. Aufsätze und Reden zur neueren Geschichte. 2 Bände, Leipzig 1918, Band 1, págs. 1-22, aqui, págs. 7-8.

204 Op. cit., pág. 11

205 MARCKS, E., «Philipp II." (nota 8), pág. 568

206 "Diesem Volke fügte Philipp II. sich ein: Er wurde dessen Ausdruck.», IBIOEM, pág. 568.

20. No obstante los trabajos de KONRAD HÄBLER, Die wirtschattliche Blüte Spaniens im 16. Jahrhundert und ihr Verfall. Berlin 1888. O el estudio de GEORG WIEBE, Zur Geschichte der Preisrevolution des 16. Und 17. Jahrhunderts. Leipzig 1895.

208 Ludwig Pfand, Philipp II. Gemälde eines Lebens und einer Zeit. München 1938. 
gran parte del hecho de que Pfandl tenía sobre todo una formación literaria, y por eso no puede satisfacer las exigencias de la historiografía. No estaba al día en las discusiones, por ejemplo, del absolutismo y del régimen político de Felipe II. Tampoco trató debidamente el primer contacto del joven Felipe con el mundo germano. Obviamente, se le escapa la importancia de la estancia de Felipe II en Augsburgo, al calificarla de año perdido. En el fondo Pfandl escribió una apología del rey español como católico y hombre siempre responsable, justificando prácticamente todas las acciones políticas del Rey Prudente. En una reseña muy extensa Richard Konetzke puso el dedo en esa llaga historiográfica ${ }^{209}$. En este contexto de la interpretación católica de Felipe II que guiaba a Pfandl, hay que mencionar el - hasta la fechaúltimo intento importante por recuperar a Felipe II para el mundo católico, la biografía sobre el Rey Prudente escrita por Reinhold Schneider ${ }^{210}$. Si bien no es una obra historiográfica, representa una corriente muy importante en la cultura del catolicisimo alemán de ver a España y a su máximo rey de la época moderna como baluartes de la religión católica. Este autor, muy prestigiado - y no sólo por los fieles a Roma-, veía en las dos culturas ibéricas una importante fuente del catolicismo. No asombra entonces que escogiese la vida de Felipe II como tema. La imagen que da es la combinación de la política con la fe. Pero aún hay más: el retrato del rey resulta un retrato de España como tal. Esta tendencia siguió vigente hasta la posguerra, como puede verse en el hecho de las dos reediciones de su obra en 1953 y 1955.

Lo que vemos hoy día -en un mundo cada vez más secularizado- es la "historización» de Felipe II. Ya pasó definitivamente a la historia como personaje que ya no es capaz de provocar grandes debates. En lo que se refiere a su imagen, hoy en día tenemos que constatar que en los grandes manuales de la historia de Alemania editados en los últimos dos decenios, prácticamente ya apenas figura. Como disponemos para la época de la obra de Ritter - escrito en 1889 y todavía de imprescindble consulta - que hizo ampliamente hincapié en las relaciones internacionales entre 1555 y 1635 en la historia alemana de la Contrarreforma, los nuevos manuales se concentran en las problemas historiográficos actuales: la confesionalización, la formación del estado moderno, el Imperio Romano-Germánico como sistema de paz colectiva, las tendencias socio-económicas o los múltiples aspectos de las mentalidades. En este contexto, y junto con las restricciones cada vez más severas en cuanto al espacio y páginas concedidas por las casas editoriales, los temas tradicionales -como la intervención extranjera- ya no figuran en los manuales. Como consecuencia, ya apenas aparece la figura del Rey Prudente.

\footnotetext{
209 Richard KonetzKe, “Zu Biographie Philipps II. von Spanien», HZ 164 (1941), págs. 316-331.
}

210 Reinholo Schnetoer, Philipp der Zweite oder Religion und Macht. Berlin 1938. 